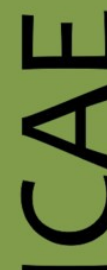

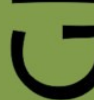

ex Instituto Archaeologico Universitatis de Rolando Eötvös nominatae

O

$\overrightarrow{0}$

山

$\leftarrow$

I

$\cup$

ه

$\leftarrow$

u

Ш

Z

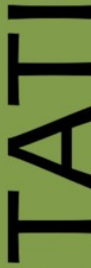

œ

ш

n

n

$\varnothing$
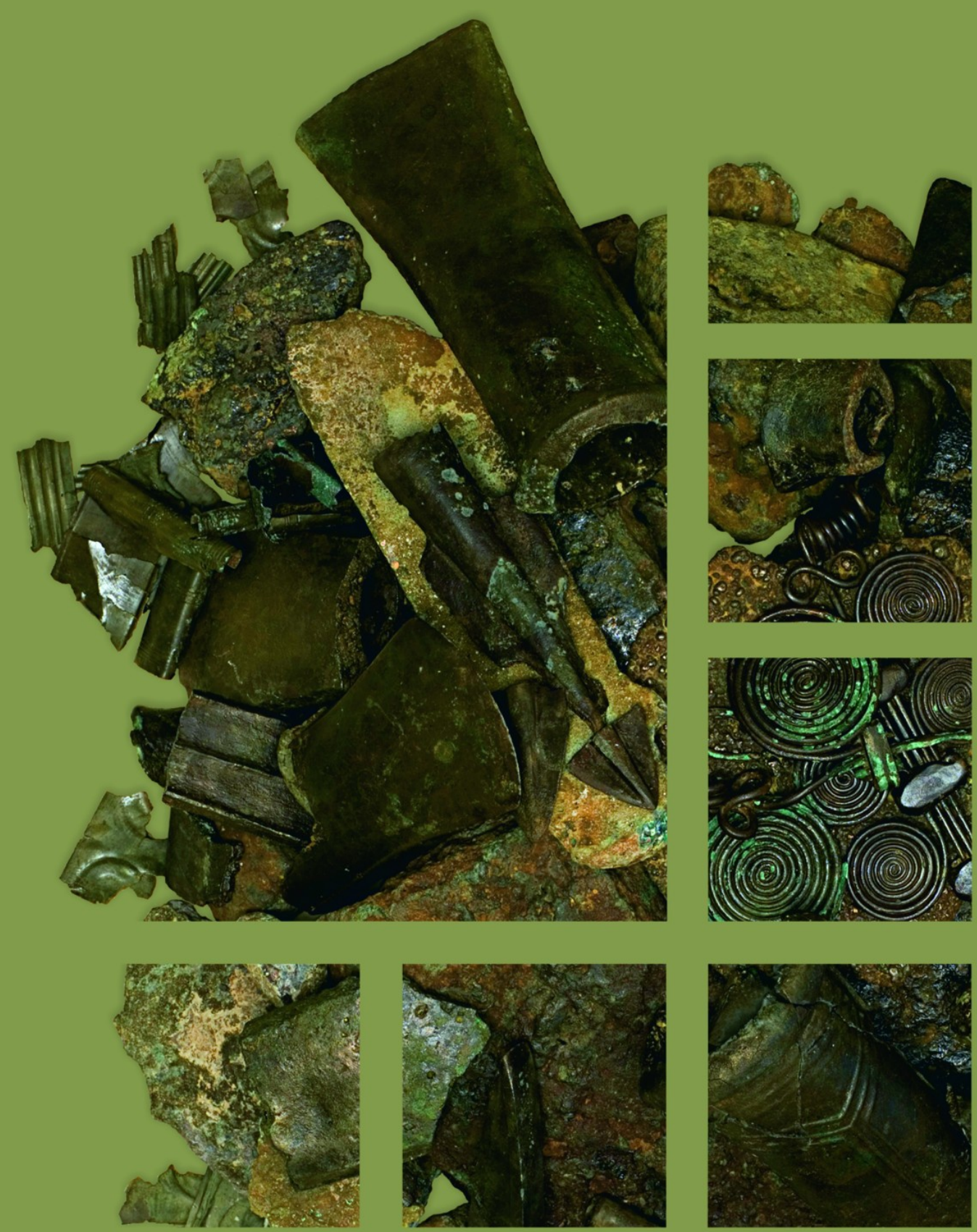


\section{Dissertationes Archaeologicae ex Instituto Archaeologico}

Universitatis de Rolando Eötvös nominatae Ser. 3. No. 2.

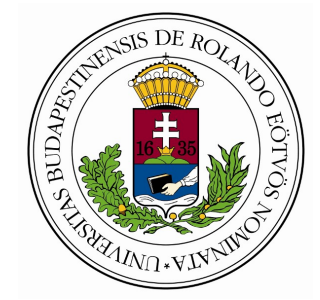

Budapest 2014 
Dissertationes Archaeologicae ex Instituto Archaeologico Universitatis de Rolando Eötvös nominatae

Ser. 3. No. 2.

Editor-in-chief:

DÁvid BARTus

Editorial board:

LÁsZló BARTOSIEWICZ

LÁSZLÓ BORHY

IsTVÁN FELD

GÁBOR KALLA

PÁL RACZKY

MiKLÓs SzABÓ

TIVADAR VIDA

Technical editors:

DÁvid BARTus

GÁBOR VÁCZI

ANDRÁs BÖDŐCS

DÁNIEL SZABÓ

Proofreading:

SZILVIA SzÖLLősI

Available online at http://dissarch.elte.hu Contact: dissarch@btk.elte.hu

$$
\begin{aligned}
& \text { PUBLIC } \\
& \text { KNOWLEDGE } \\
& \text { PROJECT }
\end{aligned}
$$

(c) Eötvös Loránd University, Institute of Archaeological Sciences

Budapest 2014 


\section{Contents}

\section{SElected PAPERS OF THE XI. Hungarian CONFERENCE on Classical Studies}

Ferenc BARNA

Venus mit Waffen. Die Darstellungen und die Rolle der Göttin in der Münzpropaganda

der Zeit der Soldatenkaiser (235-284 n. Chr.)

Dénes GABLER

A belsó vámok szerepe a rajnai és a dunai provinciák importált kerámiaspektrumában

Lajos MATHÉDESZ

Római bélyeges téglák a komáromi Duna Menti Múzeum gyújteményében

Katalin OtTOMÁNYI

Újabb római vicusok Aquincum territoriumán

Eszter SÜVEGH

Hellenistic grotesque terracotta figurines. Problems of iconographical interpretation

András SzABó

Some notes on the rings with sacred inscriptions from Pannonia

István VIDA

The coinage of Flavia Maxima Helena

\section{Articles}

Gábor TARBAY

Late Bronze Age depot from the foothills of the Pilis Mountains

Csilla SÁRó

Roman brooches from Paks-Gyapa - Rosti-puszta

András BöDőcs - Gábor KovÁcs - Krisztián ANDERKó

The impact of the roman agriculture on the territory of Savaria

Lajos JuHÁsz

Two new Roman bronzes with Suebian nodus from Brigetio

\section{FIELD REPORTS}

Zsolt MESTER - Norbert FARAGó - Attila KirÁLy

The first in situ Old Stone Age assemblage from the Rába Valley, Northwestern Hungary

Pál RACZky - Alexandra ANDERs - Norbert FARAgó - Gábor MÁRKus

Short report on the 2014 excavations at Polgár-Csőszhalom 
Preliminary Report on the first season of fieldwork in Berettyóúffalu-Szilhalom

Márton SzILÁgyi - András FüZESI - Attila VIRÁG - Mihály GASPARIK

A Palaeolithic mammoth bone deposit and a Late Copper Age Baden settlement and enclosure

Preliminary report on the rescue excavation at Szurdokpüspöki - Hosszú-dúlö II-III. (M21 site No. 6-7)

Kristóf FüLÖP - Gábor VÁcZI

Preliminary report on the excavation of a new Late Bronze Age cemetery

from fobbágyi (North Hungary)

Lőrinc TimÁr - Zoltán CzAJLik - András BöDőcs - Sándor PuszTA

Geophysical prospection on the Pâture du Couvent (Bibracte, France). The campaign of 2014

Dávid BARtus - László Borhy - Gabriella Delbó - Emese SzÁmadó

Short report on the excavations in the civil town of Brigetio (Szőny-Vásártér) in 2014

Dávid BARTus - László BorHy - Emese SzÁMADó

A new Roman bath in the canabae of Brigetio

Short report on the excavations at the site Szőny-Dunapart in 2014

Dávid BARTus - László Borhy - Zoltán CzAjlik - Balázs Holl -

Sándor PuszTA - László RuPNiK

Topographical research in the canabae of Brigetio in 2014

Zoltán CZAJLIK - Sándor BERECKI - László RUPNIK

Aerial Geoarchaeological Survey in the Valleys of the Mureș and Arieș Rivers (2009-2013)

Maxim MoRDovin

Short report on the excavations in 2014 of the Department of Hungarian Medieval

and Early Modern Archaeology (Eötvös Loránd University, Budapest)

Excavations at Castles Čabrad' and Drégely, and at the Pauline Friary at Sáska

\section{Thesis Abstracts}

Piroska Csengeri

Late groups of the Alföld Linear Pottery culture in north-eastern Hungary

New results of the research in Borsod-Abaúj-Zemplén County

Ádám Bíró

Weapons in the 10-11th century Carpathian Basin

Studies in weapon technology and methodology - rigid bow applications and southern import

swords in the archaeological material

Márta DARÓcZI-SzABó

Animal remains from the mid 12th-13th century (Árpád Period) village of Kána, Hungary

Károly BELÉNYESY

A 15th-16th century cannon foundry workshop in Buda

Craftsmen and technology of cannon moulding and the transformation of military technology

from the Renaissance to the Post Medieval Period 
István RINGER

Manorial and urban manufactories in the 17th century in Sárospatak

\section{BIBLIOGRAPHY}

László BORHY

565

Bibliography of the excavations in Brigetio (1992-2014) 


\title{
Római bélyeges téglák a komáromi Duna Menti Múzeum gyứjteményében ${ }^{1}$
}

LAJOS MATHÉDESZ

lmathedesz@gmail.com

\begin{abstract}
The Museum of Komárom, founded at the end of the 19th century, owns a remarkable collection of Roman age archaeological finds, most of which already got scientific attention in the last three decades. Roman stamped bricks constitute an exception, therefore, in the framework of this study I wish to deal with these finds. As old records contain only partial information or are missing completely, determining ther exact location of the finds posed a problem from the point of view of my research. In the study I collected the available records regarding Roman stamped bricks, which I compared with the pieces in the collection of the Museum.
\end{abstract}

Komáromban már az 1870-es évek elején felvetődött egy múzeum alapításának gondolata. ${ }^{2}$ A kezdeti sikertelenségek és kudarcok után másfél évtizeddel később, 1886. december 19-én 116 taggal megalakul a Komárom Vármegyei és Komárom Városi Történeti és Régészeti Egylet. Alapszabályát a belügyminiszter 1887. március 30-án hagyta jóvá, amelyet az egylet április 17-i közgyülésén hirdettek ki. ${ }^{3}$

Még a múzeum alapításának terve előtt, már az 1869/70-es tanévben oktatási célokra létrejött a helyi bencés gimnáziumban egy régiségtár, amelyben történeti és régészeti emlékeket is elhelyeztek. A helyiek ezt a gyűjteményt „múzeumnak” is nevezték. A régiségtár később vétel útján gyarapodott, amelyről beszámolnak az intézmény által kiadott évkönyvekben. ${ }^{4}$

A kezdeti időszakban a múzeum gyűjtőterülete Komárom és környékére terjedt ki. Így a múzeum gyüjteményében nagyon sok római emlék került Komárom környéki lelőhelyekről. Ezen római gyưjtemények az elmúlt három évtizedben részlegesen katalógus formájában feldolgozásra kerültek. Elsőként a ládikaveretek, zárak, fülek, kulcsok, szögek és páncéltöredékek, ${ }^{5}$ majd kőemlékek, ${ }^{6}$ terra sigillaták, ${ }^{7}$ pénzek, ${ }^{8}$ lámpák és világítóeszközök ${ }^{9}$ és a csontfa-

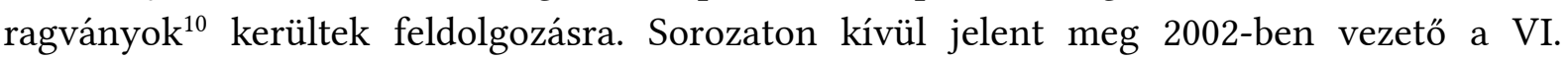
Bástyában berendezett kőtárhoz. ${ }^{11}$ A múzeum gyüjteményében nagy számmal előfordulnak bélyeges téglák is, amelyeket az elmúlt közel 130 év során többször is feldolgoztak, de csak részlegesen publikáltak. Ezen tanulmányban ezt a hiányosságot próbálom pótolni.

\footnotetext{
1 Ezúton is szeretnék köszönetet mondani a Komáromi Duna Menti Múzeum minden munkatársának, hogy lehetőé tették a leletek feldolgozását és a munkám során készségesen segítettek.

2 FEHÉRVÁRYOVÁ 1986, 11-12.

3 MÁCZA 2011, 11.

4 FEHÉRVÁRYOVÁ 1986, 13.

5 GASPÁR - RATIMORSKÁ 1983, 1-27.

6 RATIMORSKÁ 1984, 1-62.

7 Kuzmová 1992, 1-107, Tab. 1-59.

8 BAKOS - LÁNYI - TORBÁgYi 1994, 1-88.

9 ŽUNDÁLEK - ŽUNDÁLEKOVÁ 2012, 1-224.

10 HRNČIARIK 2012, 1-160.

11 HARL - LőRINCZ 2002, 1-64.
} 
A múzeum gyüjteményében fellelhető leletek lelőhelye sok esetben nem megállapítható, mivel a legrégebbi leltárkönyvek, amelyek segítségünkre lehetnének az idők folyamán elkallódtak. A legrégebbi megmaradt leltárkönyv 1905-ből származik, ${ }^{12}$ ám nem tartalmazza egyetlen egy bélyeges tégla leírását sem. A kezdeti évek múzeumi gyarapodásáról csakis az egylet által kiadott évi jelentésekből tudunk tudomást szerezni illetve az itt megjelent különböző tanulmányokból.

Az első 1887-es évkönyvben Gyulai Rudolf „Adalékok megyénk római hódoltsága korához” című tanulmányában többek között foglalkozik a tájainkon állomásozó különböző csapattestekkel. Számunkra érdekes lehet a Legio I Adiutrix, amelynek leírása szerint nyolc variánsa található meg az egylet múzeumában, amelyek mind Ó-Szőnyről származnak. ${ }^{13}$ Mivel konkrét variánsokat nem említ ezért lehetetlen ezen leletek azonosítása a múzeum gyưjteményében. Ezen kívül még megemlíti a szintén Brigetióból származó Legio XI Claudia bélyegét is, amelyből egy darab az egylet, egy pedig a Magyar Nemzeti Múzeum gyüjteményében lelhető fel. ${ }^{14}$ A múzeum gyüjteményében található egy LEG XI CPF bélyeg (Kat. 6), ám közel sem biztos, hogy megegyezik a Gyulai által leírt lelettel. Ezen kívül még megemlíti, hogy Vexillatio III és IV bélyegből két-két darab található az egylet múzeumában. ${ }^{15}$ Ezzel szemben 2013 ban csak egy tégla töredéken találtam planta pedis keretelésben egy Vexillatio III bélyeget (Kat. 10). Gyulai szerint a Cohors VII BR ANT bélyegű téglából a múzeum gyűjteményében öt variáns volt fellelhető. ${ }^{16}$ Ezzel szemben a feldolgozott leletek között csak egy tegula töredéken találtam egy $\mathrm{COH}$ ] VII BR ANT bélyeget (Kat. 8). Illetve még említést tesz egy Vincentia nevü cohorsról is, amelynek egy bélyege található meg a múzeum gyüjteményében. ${ }^{17}$

Szintén ebben az évben Dr. Cseley János városi főorvos ajándékozott a múzeumnak 82 római érmét, 2 római bögrét, 3 korsót, egy fazekat, 8 mécsest, egy bronz vésőt, egy serpentin vésőt, egy agyag oltárkát, egy torzarcot terra sigillatából, egy feliratos oltárt és többrendbeli római bélyeges téglát. ${ }^{18}$ Hogy milyen és hány darab római bélyeges téglát adományozott Dr. Cseley a múzeumnak a leírásból nem derül ki. Szintén ebben az évben Voetter Ottó őrnagy többek között sok más római lelettel együtt 36 feliratos téglát is adományozott a múzeumnak. ${ }^{19}$

1888-ban az egylet 16 bélyeges téglához jut vétel útján. Ezek pedig a következők: 1 . RF RE VPD; 2. [QVA]DRIBVR ARA; 3. LVPICINO TRB; 4. LEG X G PF (retrográd); 5. LEG XI C PF; 6. VINCENTI (retrográd); 7. SOL ALA (retrográd); 8 . LICANNVS; 9. VL XIII; 10. VEXILATIO III; 11. COH VII BR CORD; 12. COH VII BR MA(crini); 13. [C VAL C]ONST KAR; 14 LEG I ADIV MACRIF; 15 . TERENTIA(nus); 16. VEXIL II. ${ }^{20}$ A fentebb már leírt LEG XI C PF és a VEXILATIO III kivételével a fent felsorolt leletek közül egyértelműen a múzeum gyűjteményében tudjuk azonosítanni a QVA]DRIBVRVM (QVADRIBVRGIVM) (Kat. 11), a LEG X GPF retrográd (Kat. 5), a VINCENTI retrográd (Kat. 14), a SOL ALA retrográd (Kat. 13), a COH VII BR COR (Kat. 9) és a [C VAL C]ONST KAR (Kat. 12) tégla bélyegeket.

\footnotetext{
12 Ezúton szeretnék köszönetet mondani Marek Gere régésznek, hogy a munkám során hozzáférést biztosított a feldolgozott leletekhez és az leltárkönyvekhez is.

13 Gyulai 1888a, 6.

14 Gyulai 1888a, 7.

15 Gyulai 1888a, 7.

16 Gyulai 1888a, 7.

17 Gyulai 1888a, 7.

18 Gyulai 1888b, 42.

19 Gyulai 1888b, 48.

20 Gyulai 1889a, 13.
} 
Gyulai Rudolf az egylet titkára, aki többek között az egylet 1887-1892 között megjelent hat évkönyvét is szerkesztette, 1889-ben összeállította a múzeum egylet első nyilvános kiállítását, amit június 9-én nyitottak meg. ${ }^{21}$ A kiállítás a református kollégium nagytermében volt megtekinthető 1889 és 1897 között. ${ }^{22}$ Erre az alkalomra Gyulai Rudolf megírt egy vezetőt, amely a „Kalauz a Komárommegyei és Városi Történet-Régészeti-egylet Muzeumában” címet viseli. Ebben a 16 oldalas vezetőben részlegesen leírta a kiállított tárgyakat. A 13. oldalon említést tesz arról, hogy a feliratos köveket, bélyeges téglákat és római érmeket még nem lehet bemutatni a közönségnek, mivel rendezésük még nincs befejezve. ${ }^{23}$

A kezdeti lendület az 1890-es években megtört. Csökkent a tagok száma, csak lassan növekedett a gyüjtemény. 1890 óta az egyletben nem tartottak előadásokat, 1893 óta nem adta ki az évkönyvét. Több problémával kellett szembenézniük. A kezdetekhez hasonlóan nem rendelkeztek állandó székhellyel. A tárgyak 1897-ig a bencés kollégium nagytermében voltak elhelyezve, ahonnan az újonnan felépült Törvényszéki palotába kerültek. ${ }^{24}$ Ezen év májusában Gyulai megrendezte a múzeum második kiállítását, majd 1897 nyarán Füssre került. Távozása előtt Weszelovszky Jánosnak adta át a múzeum gyűjteményét. ${ }^{25}$ Weszelovszky Jánosra nagy feladatok vártak, újra kellett élesztenie a múzeum egyletet.

Az egylet átszervezése csak 1900-ban valósult meg. Az egylet a Komárom vármegyei és városi Muzeum-egyesület néven folytatta tovább tevékenységét. Az átszervezés után újra megjelenik a múzeum egyesület évkönyve. Az újonnan megjelent múzeumi évkönyvek már nemcsak tanulmányokat, a gyüjtemény gyarapodását, hanem ásatási beszámolókat is tartalmaznak.

Számunkra érdekes lehet az 1901/1902. évi évkönyvben a múzeum gyarapodásnál említett herkályi ásatás, amelyből egy vasszekerce és nyolc különféle alakú római bélyeges tégla LVPICINI TRB felirattal került a gyüjteménybe. ${ }^{26} \mathrm{Az}$ ásatásoknál röviden megemlítik, hogy bejelentés folytán értesültek, arról, hogy a herkályi erdőben egy domb van, amely erősebb dobbanásra kong. A terület kutatását az igazgató elrendelte és báró Solymossy László engedelmével végre is hajtották. Az ásatás hónapokon keresztül folyt. Eredménye a leírás szerint egy római castellum lett, amelyből feliratos téglák, harci eszközök és edénytöredékek kerültek elő. ${ }^{27} \mathrm{~A}$ szerző még megemlíti, hogy a leletekről bővebben az évkönyvben található értekezésben olvashatunk. Ám ezen évkönyvben további információkat a herkályi ásatásokról nem, csak a monostoriról szerzünk. Valószínúleg egy és ugyanazon ásatásról illetve lelőhelyről lehet szó, mivel a leírások nagy részben megegyeznek. Herkály leírását megtalálhatjuk Fényes Elek „Komárom vármegye leírása“ (1848) illetve „Magyaroszág geographiai szótára“ című könyvében Herkál puszta alatt. A leírás szerint keletre Új-Szőny, délre Csém, nyugatra Ács, északra kis részben pedig a Duna határolja. ${ }^{28}$

Milch Ármin „A monostori ásatás“ című beszámolójából megtudhatjuk, hogy Szitter uradalmi erdész jelentéséből szereztek róla tudomást, hogy az ácsi erdő Duna felőli részén, mintegy 100 méterre keletre az ácsi határtól, közvetlen a Duna partján álló magaslaton valami

\footnotetext{
21 MÁcza 2011, 11.

22 RATIMORSKÁ - VirÁgH 1986, 164.

23 Gyulai 1889b, 13.

24 FEHÉRVÁRYOVÁ 1986, 18-19.

25 FeHÉRVÁryová 1986, 20.

26 WeszelovszKy 1903a, 13.

27 WeszelovszKy 1903b, 15.

28 FÉNYES 1984, 102-103, FÉNYES 1994, 234.
} 
üregnek kell lennie, mert arra rálépve kongás hallatszik. ${ }^{29} \mathrm{~A}$ beszámolóból továbbá megtudjuk, hogy Weszelovszky múzeumőr próbaásatást kezdett, amelynek eredménye két fal maradványa lett. A falak által határolt területen nagyon sok tegula töredék került elő LVPICINI illetve LVPICINO TRB felirattal. ${ }^{30}$ A sikeres próbaásatások után a múzeum-egyesület elhatározta a monostori ásatások folytatását, aminek vezetésével Weszelovszky Jánost és Milch Ármint bízták meg. ${ }^{31} \mathrm{Az}$ ácsi erdőben feltárt őrtorony egy 9,55 x 9,55 m alapterületű négyszög alakú épület, amely a leírás szerint $1 \mathrm{~m}$ vastag oldalfalakkal és $1,2 \mathrm{~m}$ vastag alapfalakkal rendelkezett. A falak a legmagasabb megmaradt részen a $80 \mathrm{~cm}$ magaságot érték el. ${ }^{32} \mathrm{Az}$ ásatás elején talált nagy mennyiségü „részben lapos“ (tegula) és „részben félgömbölyü“ (imbrex) töredék a leomlott tető részét képezte. Egyetlen teljesen ép darabot sem találtak köztük. A már fentebb említett LVPICINI illetve LVPICINO TRB feliratú bélyeges téglák kerültek itt elő. Milch Ármin szerint az őrtornyot tűz pusztította el, ezt bizonyítják az égési rétegek. ${ }^{33}$ Ezen kívül, még említést tesz néhány $8 \mathrm{~cm}$ vastag tégladarabról (later), amelyek közül egyen a TERENTIANVS TRB bélyeg található. ${ }^{34}$ 2013-ban a leletek feldolgozása során a múzeum gyüjteményében 4 darab LVPICINI TRB (lásd Kat. 16-18, 21) illetve 2 darab LVPICINO TRB $($ Kat. 15, 19) egész, illetve töredékes bélyeget találtam. Két esetben a töredékességük miatt nem megállapítható, mely bélyegről is van szó (Kat. 20,22). TERENTIANVS TRB bélyegű részleges megőrződésủ bélyeget csak egy darabot találtam (Kat. 23). Mivel a bélyegek esetében pontos leírással nem rendelkezünk, ezért száz százalékos biztonsággal nem állíthatjuk, hogy a Weszelovszky János és Milch Ármin által ismertetett leletek megegyeznek a múzeum mai gyűjteményében felelhető leletekkel.

Feltételezhetően a két ásatás leírása egy és ugyanazon lelőhelyre vonatkozik, csak a két ásató a lelőhely leírását másképp ismertette.

Az 1903. évi értesítőből megtudjuk, ahogy azt a pusztamonostori ásatásról készült beszámolóban Milch Ármin leírta a közeljövőben további római érődítmények kerülhetnek elő. Kiderül, hogy jóslata beigazolódott, mivel Pály Zsigmond ácsi szőlőjében szőlő rigolirozása közben sorfalazatra akadtak. A szomszédos területen végzet próbaásatások eredményei alapján 2,5 - 2 méter mélyen a föld alatt épületek falai találhatók. Az itt talált tégla töredékeken LEG I AD és $\mathrm{COH}$ IV bélyegek találhatók. ${ }^{35} \mathrm{~A}$ feliratos téglák feldolgozása közben $\mathrm{COH}$ IV bélyegü lelettel nem találkoztam, míg a LEG I AD bélyeg és annak külömnböző változatai az egyik leggyakoribbak. Csak A LEG I AD (teljes illetve részlegesen megőrzödésű) bélyeg egyértelműen 43 leleten (Kat. 25-66) azonosítható. Külön soroltam be a katalógusba azon téglákat, amelyek felszínén két bélyeg töredékét véltem felfedezni. Összessen négy ilyen feliratos téglát találtam a múzeum gyüjteményében, ebből egyen biztosan a LEG I AD illetve a töredékes LEG] I AD bélyeg szerepelt (Kat. 225). További két esetben is fennáll, hogy a LEG I AD bélyege szerepelhetett, de a részleges megőrzödésük miatt ez egyértelműen nem megállapítható (Kat. 223-224).

1906-ban kezdődtek meg az Izsa-Leányvári ásatások. Az ásatásokat Tóth Kurucz János izsai származású tanár, amatőr régész végezte. Feltételezése szerint a leányvári táborban a Legio I Adiutrix egy osztálya székelt, erről tanúskodik a temérdek bélyeges fedő cserép, amelyek

29 Milch 1903, 39.

30 Milch 1903, 39.

31 Milch 1903, 39.

32 Milch 1903, 41.

33 Milch 1903, 42.

34 Milch 1903, 43.

35 Weszelovszky 1904, 10. 
mind ezzel a jelzéssel vannak ellátva több változatban. ${ }^{36} \mathrm{~A}$ bélyeg változatokat konkrétan nem ismerteti, csak megjegyzi, hogy többé-kevésbé rövidítettek és akad közte retrográd nyomású is. Leírása szerint néhány téglán kecske és kutya lábnyomokat is talált, amelyek még a kiégetés előtt kerültek rájuk ${ }^{37}$. A múzeumban feldolgozott 239 feliratos tégla közül mindösszessen csak egyen találtam kutya tappancs nyomát, amely egy LEG I ADI - retrográd nyomásos bélyeg után szerepelt (Kat. 183). Az 1906-os ásatási szezonban leírása szerint csak egy téglán talált az első segédlégió bélyegétől különböző feliratot, mégpedig a COH VII BRIC AA bélyeget. ${ }^{38} \mathrm{~A}$ múzeum gyűjteményében mindösszessen csak három téglán találtam $\mathrm{COH}$ kezdetű bélyeget (Kat. 7-9), de egyiken sem szerepelt a Tóth Kurucz János álltal ismertetett felirat.

Az első ásatási év után Tóth Kurucz János nem csak az épp aktuálisan felszínre került leleteket, hanem az Izsa-Leányvárról származó régebbi leleteket is ismertette. Így megjegyzi, hogy pár évvel azelőtt egy izsai embertől két darab feliratos cserepet kapott. Az egyiken a LEG I AD, míg a másikon egy kétsoros LEG I AD BOMICRESC bélyeg szerepel. Az egyik leletet Brigetióban, a másikat viszont Leányváron találta, de már nem emlékszik rá, hogy melyiket hol. ${ }^{39}$ Feltételezhetően a LEG I AD / BOMICRESC két soros bélyeg Brigetioból származik, mivel innen már kerültek elő hasonló bélyegek. ${ }^{40} \mathrm{~A}$ múzeum gyüjteményében található egy LEG I AD / BOMICRESC feliratú bélyeg (Kat. 1).

Elméletileg a Leányvári leletek pontos leltárát meg kellene találnunk az aktuális év leltárkönyvében, ám az ásatások mindig az adott év utolsó tételei alatt szerepelnek. Ám ezek csak egy számadatot tartalmaznak, hogy hány darab lelet került be az ásatás folytán a gyüjteménybe.

Ha már az leltárkönyvekben nem sikerült információt szerezni a leletekről, további információkat találtam Tóth Kurucz János hagyatékában, amit 2013 őszén áttanulmányozhattam. ${ }^{41} \mathrm{~A}$ hagyatékban találtam feljegyzéseket az ásatásokon előkerült leletekről, de sajnos a leggyakoribb bélyeges téglák, a LEG I AD bélyeg variációit csak számszerüsítve jegyzi fel, így nem tudjuk azonosítani hogy mely leletek származhatnak Tóth Kurucz János ásatásaiból.

1907-ben folytatódott Izsa-Leányvár feltárása. Ebben az ásatási szezonban is nagy számban kerültek elő bélyeges téglák. Ahogy az előző évekből már ismert, pontos feljegyzéssel a számukról és a bélyegeikről nem rendelkezünk. Tóth Kurucz János feljegyzése szerint a legtöbb téglán a Legio I Adiutrix bélyege szerepelt. Ahogy feljegyzi legalább 10 féle változatban, néha csak egy-két betű, néha az egész nyomás retrográd. Néhány leleten Pia Fidelis toldásokat is felfedezni vélt. ${ }^{42}$

A Legio I Adiutrix külömböző bélyegein kívül az 1907. évi ásatási szezonban még a következő téglabélyegek kerültek elő: egy darab QVADRIB, több darabon LVP és ICINI töredékek illetve két töredéken a ...TIANVS T... felirat szerepel. ${ }^{43}$ A LVP és ICINI egyértelműen a LVPICINI TRB bélyeg volt, míg a TIANVS T töredéket feltételezhetően a Terentianus Tribunus bélyegre egészíthetjük ki. 2013-ban a múzeum gyüjteményében csak egy Terentianus Tribunus (Kat. 23) részleges bélyegét találtam, amely feltételezhetően nem Tóth Kurucz János ásatásából

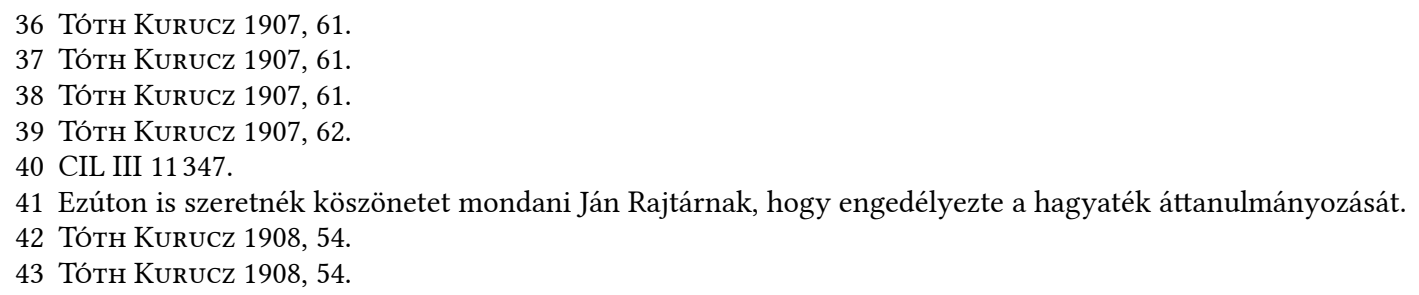


származik. A Terentianus Tribunus bélyegnél megjegyzi, hogy 1907 őszén a pilismaróti ásatásokon, amit Dr. Finály után folytatott, ő is egy sereg ilyen bélyeget talált. ${ }^{44}$

Tóth Kurucz János hagyatékában az 1907. évi ásatások jegyzéke között a következő feljegyzésekre bukkantam: 3 darab Lupicina jelzésű cserép, 1 darab COH VII Brigetiam..., 24 darab LEG I AD cserép, 10 darab padozat tégla típus LEG I A bélyeggel. Ezen kívül még megemlít 6 darab kerek alakú téglát (feltételezhetően hypocaustum oszlop részei lehettek), 4 darab fedőcserép és 5 darab hypocaustum fütővezeték tégla (tubulus?).

Ha összehasonlítjuk a cikkben leírtakat és a hagyatékban feljegyzett leleteket, akkor rádöbbenünk, hogy a két lista korántsem egyezik. A két listán szintúgy szerepelnek a Legio I Adiutrix és a Lupicinus Tribunus bélyegek. Ám míg a cikkben Quadriburgium és Terentianus tribunus bélyegeket említ, a leletek leírásánál ezeket nem sorolja fel. Ezzel szemben említést tesz egy Cohors VII Brigetiam... ? bélyegről. Hasonló COH VII BRIC AA bélyeget említ az 1906-os ásatási beszámolóban. Megemlíti, hogy ebből a bélyegből már Brigetioban is többet is találtak és kétféleképpen olvassák: vagy Cohors VII Breucorum vagy Cohors VII Brigetiana-nak. ${ }^{45}$

Az 1908. évi ásatási szezonban két darab LVP és TRIB (ami szintén a Lupicini tribunus bélyegre kiegészíthető) kivételével az összes többi bélyeges téglán a Legio I Adiutrix bélyege illetve néhány esetben Pia Fidelis toldással ellátott variációja szerepelt. ${ }^{46}$ A LEG I AD bélyeggel már fentebb foglalkoztam. A LEG I AD PF bélyegü téglából (egész illetve részleges) összesen 11 darab található a Duna Menti Múzeum gyüjteményében (Kat. 113-123).

Az 1908-as leltárkönyvben a 56. szám alatt a következő bejegyzést találhatjuk: „ különféle római régiségek a leányvári ásatásból - 234 darab“. Tóth Kurucz János hagyatékában megtalálható a feltárt leletek listája. Számunkra érdekes, hogy feljegyzése szerint 20 bélyeges fedőcserepet és téglát említ. Hogy pontosan milyen bélyegekről van szó, ebből a feljegyzésből nem derül ki, de feltételezhetően a Legio I Adiutrix különböző variánsairól lehet szó.

1909-ben is folytatódott a leányvári ásatás. Az ásató leírása szerint a leletek ebben az évben nem nagy számban kerültek elö. ${ }^{47}$ Az aktuális év leltárkönyvében a 121. szám alatt ezt az állítását megerősíti, mivel a feljegyzés szerint az ásatásokból „csak“ 69 darab római tárgy és 29 érem került be a múzeum gyűjteményébe. Tóth Kurucz hagyatékában az erre az évre vonatkozóan 20 bélyeges cserepet említ. Érdekes, hogy az egész listát ceruzával írták, csak a téglákra vonatkozó részt jegyezték fel tollal. ${ }^{48}$

Tóth Kurucz János hagyatékában található feljegyzés az 1912-ben előkerült leletek listájával. A lista végén ez a bejegyzés szerepel: „ezen kívül különböző méretű és alakú bélyeges téglák, bélyeges fedőcserép töredékek." Az 1912-es ásatási szezonban végzett munkákról és leletekről nem közölt cikket a múzeum aktuális évi évkönyvében.

Alapi Gyula a Komáromi Múzeum igazgatója „A Komáromi Múzeum római régiségei“ című cikkében, ahogy a cím is utal rá, a múzeum gyüjteményében található római leleteket, lelettípusokat vette számba. A bélyeges tégláknál megjegyzi, hogy azok és a cserepek százai egyenlőre a földön vannak lerakva. Kivételt csak azokkal tettek, amelyeken nem a LEG I ADI felirat, 
hanem más csapattest vagy katonai tribunus neve szerepelt. Ám megjegyzi, hogy a múzeum gyűjteményében a legnagyobb részt az első segédlégió és annak bélyegei találhatók meg. ${ }^{49}$

Szilágyi János „A Pannoniai bélyeges téglák“ című munkájában is foglalkozik a Komáromi Múzeum bélyeges tégláival. Kivétel nélkül az összes téglát a múzeum gyüjeményéből Ószőny lelőhely alatt tüntet fel. ${ }^{50}$ Néhány izsa-leányvári bélyeges téglát, amit munkájában megemlít csakis a Pozsonyi Zemedelské Múzeum illetve Pozsonyi Múzeum gyűjteményében ismerteti. ${ }^{51}$

Az ószőnyi lelőhelyűként feltüntetett leletek között leggyakoribb a Legio I Adiutrix és annak különböző bélyeg variációi. ${ }^{52}$ Ezen kívül egy bélyeg a Legio I Noricorum, ${ }^{53}$ egy a Legio II Itali$\mathrm{ca}^{54}$ kétsoros, két példányon a Legio X Gemina ${ }^{55}$ egyen a Legio XI Claudia ${ }^{56}$ bélyege szerepel. Ezen leletek közül napjainkban ténylegesen csak a Legio II Italica kétsoros bélyege (Kat. 2), három példány a Legio X Gemina különböző variánsaival (Kat. 3-5), egy példányon pedig a Legio XI Claudia (Kat. 6) bélyege található meg.

A legiók kivételével még egy ép és egy töredékes példányon a Vexillatio III ${ }^{57}$, egy ép és egy csonka példányon a V L XIIII et $\mathrm{XV}^{58}$ bélyeget ismertette Szilágyi. A cohorsok közül összefüggésbe hozza a két példányt a Cohors VII Breucorum Antoniniana ${ }^{59}$ jelzővel, egy példányon a Cohors VII Breucorum Gordiana ${ }^{60}$ bélyeg, egy elmosódott példányon pedig csak a $\mathrm{COH} .{ }^{61}$ betűk olvashatók ki. A fent felsoroltak közt napjainkban egyértelműen a múzeum gyűjteményében megtalálható a Vexillatio III (Kat. 10), egy példányon a Cohors VII Breucorum Antoniniana (Kat. 8), egy példányon a Cohors VII Breucorum Gordiana (Kat. 9) és a Cohors töredékes (Kat. 7) bélyege.

Szilágyi 1933-as munkájában említést tesz továbbá Lupicini Tribunus ${ }^{62}$ (összesen 10 példány) és Terentianus tribunus ${ }^{63}$ (legalább négy példányon), Quadriburgium ${ }^{64}$ (egy példányon) és C Val Const $\operatorname{Kar}^{65}$ (egy töredékes példányon) bélyegeiről. A Szilágyi János által felsorolt bélyegek közül napjainkban a Lupicinus Tribunus illetve Lupicino Tribunus (Kat. 15-22) bélyegből nyolc példány, Terentianus Tribunus (Kat. 23) bélyegből egy töredékes példány, míg a töredékes Quadriburgium (Kat. 11) és a C Val Const Kar (Kat. 12) magángyártótól is egy-egy példány található meg.

Szilágyi munkájában a komáromi leletekkel kapcsolatban mindig Ószőny lelőhelyet tünteti fel. Leltári számokat ezen leletek mellett nem ismertet. Munkája írásakor elméletileg még rendelkezésére állhattak a múzeum legrégebbi leltárkönyvei, amelyek valamikor a két világháború között kallódtak el. ${ }^{66}$

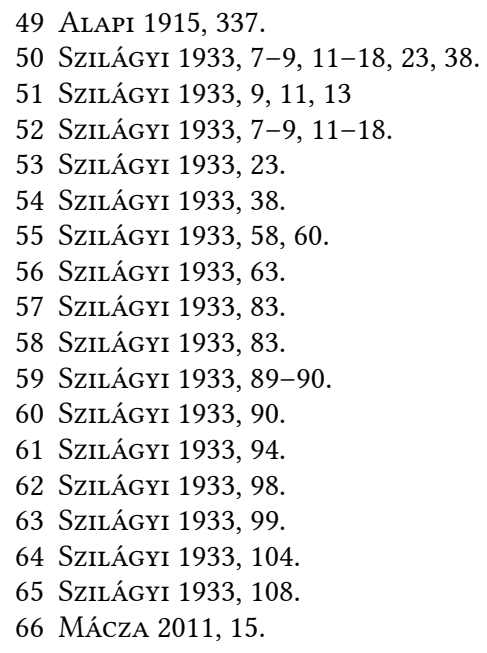


A Szilágyi János által felsorolt leletek illetve a mai gyűjteményben fellelhető bélyegek számában azért is lehet eltérés, mivel 1951-ben a római kori gyüjtemény nagy részét a pozsonyi Szlovák Múzeumba, a képzőművészeti gyűjtemény 67 darabját a bajmóci képtárba szállították. Később az elszállított tárgyak nagy része visszakerül a komáromi múzeumba. ${ }^{67}$

A régi leltárkönyvek hiánya miatt a múzeum külsős munkatársakkal 1955-től a leletekről új evidenciát hoz létre. ${ }^{68}$ A múzeumban található tárgyak új leltári száma római kettessel, kötőjellel és számmal látták el. A leletek feldolgozása közben pár esetben figyelmes lettem arra, hogy egy-egy téglán ugyanaz a szám szerepel. Néhány esetben az leltári szám kopott, illetve nem egyértelműen kivehető, ebben az esetben a számot kérdőjellel jelöltem. Szintén feltűnt hogy az leltárkönyvben leírt lelet nem minden esetben egyezik meg a tényleges bélyeggel a téglákon. A feldolgozásom során a katalógus részben a leletek rövid leírása után a leletek méreteit illetve leltári számát tüntetem fel.

1972-ben Brünnben került beadásra Jozef Bujna diplomamunkája, amelyben az akkori Szlovákia területéről származó bélyeges téglákkal foglalkozik. Elmondása szerint munkájában több mint 1200 bélyeges téglát gyüjtött össze. ${ }^{69}$ Sajnos a munka soha nem jelent meg és mivel a kutató később már nem a római korral foglalkozott, a kutatási eredményét sem publikálta. Sajnos a munka hozzáférhetetlensége miatt nem állt módomban áttanulmányozni, de feltételezhetően ő is foglalkozott a Komáromi Múzeum gyűjteményében található bélyeges téglákkal. 


\section{Katalógus}

(A méretek jelölése: hosszúság $\mathrm{x}$ magasság $\mathrm{x}$ vastagság)

\section{LEG I AD / BOMICRESC}

Kat. 1. Bélyeges tégla töredéke, tegula.

Kétsoros bélyeg. Első sorban: LEG I AD, míg a másodikban BOMICRESC található. A két sort egy vonal választja el. Az első sort egy faág motívum zárja le.

Méret: 12,5 x 6-7,2 × $3 \mathrm{~cm}$

Leltári szám: nincs

\section{LEG II ITAL /}

Kat. 2. Bélyeges tégla töredéke.

Kétsoros bélyeg. Első sor LEG II ITAL, második sor töredékes - olvashatatlan.

Méret: v. $3 \mathrm{~cm}$

Leltári szám: II-2165

\section{LEG X GE PF}

Kat. 3. Bélyeges tégla töredéke, tegula.

LEG X GE PF bélyeg planta pedis keretben.

Méret: $12-16$ x 18 x 3,9 cm

Leltári szám: nincs

\section{LEG X G PF}

Kat. 4. Bélyeges tégla töredéke, tegula.

[LE]G X G PF bélyeg planta pedis keretben.

Méret: v. $2,6 \mathrm{~cm}$

Leltári szám: II-2232

\section{LEG X G PF - retrograd}

Kat. 5. Bélyeges tégla töredéke, tegula.

Egyszerü keretben retrográd LEG X G PF bélyeg.

Méret: v. $2 \mathrm{~cm}$

Leltári szám: II-2144

\section{LEG XI C PF}

Kat. 6. Bélyeges tégla töredéke, tegula?

Tabula ansata keretelésben (aminek felső része nem teljesen vehető ki) LEG XI C PF bélyeg.

Méret: v. 3,9 cm

Leltári szám: II-2174

\section{СOH...}

Kat. 7. Bélyeges tégla töredéke, tegula.

Planta pedis keretben egy erősen sérült bélyeg található. A bélyegből csak az első három betű: $\mathrm{COH}$ vehető ki.

Méret: v. 3-3,4 cm

Leltári szám: nincs

\section{COH VII BR ANT}

Kat. 8. Bélyeges tégla töredéke, tegula.

Bélyeg: $\mathrm{COH}]$ VII BR ANT

Méret: v. 2,8-3 cm

Leltári szám: nincs

\section{COH VII BR COR}

Kat. 9. Bélyeges tégla töredéke, tegula?

COH VII BR COR bélyeg tabula ansata keretelésben (csak a végén őrződött meg). A C BR CO betűk és a keretelés felső része csak részlegesen őrződött meg.

Méret: v. 3,5 cm

Leltári szám: II-2153 áthúzva, II-2212

\section{VEXILATIO III}

Kat. 10. Bélyeges tégla töredéke, tegula?

Planta pedis keretben VEXILATIO III bélyeg szerepel.

Méret: v. $2-3,8 \mathrm{~cm}$

Leltári szám: II-2919

\section{Quadriburgium}

Kat. 11. Bélyeges tégla töredéke.

Bélyeg: QVA]DRIBVRVM

Méret: v. $5,4 \mathrm{~cm}$

Leltári szám: II-4319

\section{VAL CONST KAR}

Kat. 12. Bélyeges tégla töredéke, tegula?

Bélyeg: C VAL C]ONST KAR. Az O betű csak részlegesen őrződött meg. 
A szavak közt háromszög formájú interpunkció.

Méret: v. 1,6-2,2 cm

Leltári szám: II-2157

\section{SOL ALA - retrográd}

Kat. 13. Bélyeges tégla töredéke, tegula.

Retrográd bélyeg: SOL ALA.

Méret: 6,2-6,5 x 13,4-13,6 × $2 \mathrm{~cm}$

Leltári szám: II-2807

\section{VINCENTIA - retrograd}

Kat. 14. Bélyeges tégla töredéke, tegula?

Bélyeg: VINCENTIA - retrográd. A bélyeg nehezen kivehető.

Méret: 9 x 17,7 x 3,3 cm

Leltári szám: II-2904

\section{LVPICINI TRB / LVPICINO TRB}

Kat. 15. Bélyeges tégla töredéke, tegula.

Bélyeg: LVPICINO TRB - nem egyforma nagyságú betük.

Méret: $28,6-30,3$ x 10,2 x $3 \mathrm{~cm}$

Leltári szám: II-2209

Kat. 16. Bélyeges tégla töredéke, tegula?

Bélyeg: LVPI]CINI TRB

Méret: v. 3,6 cm

Leltári szám: II-2190

Kat. 17. Bélyeges tégla töredéke, tegula.

Bélyeg: L]VPICINI TRB

Méret: 15,8 x 16 x 3-3,2 cm

Leltári szám: II-2148

Kat. 18. Bélyeges tégla töredéke, imbrex.

Bélyeg: L]VPICINI [TRB - az L,V és I, T betűk csak részlegesen őrződtek meg.

Méret: v. 2,5 cm

Leltári szám: nincs

Kat. 19. Bélyeges tégla töredéke, tegula.

Bélyeg: LV]PICINO TRB - a betűk nem egyforma nagyságúak. A $\mathrm{P}$, I és $\mathrm{N}$ betűk csak részlegesen őrződtek meg.

Méret: v. $3 \mathrm{~cm}$

Leltári szám: nincs
Kat. 20. Bélyeges tégla töredéke, imbrex.

Bélyeg: LVPI[

Méret: v. 2,4 cm

Leltári szám: II-2166

Kat. 21. Bélyeges tégla töredéke, tegula.

Bélyeg: LVPICINI] TRB - az I és T betűk csak részlegesen őrződtek meg.

Méret: v. $3,2 \mathrm{~cm}$

Leltári szám: II-2189

Kat. 22. Bélyeges tégla töredéke, imbrex.

Bélyeg: ]RB - a betűk nehezen kivehetők.

Méret: v. 2,5 cm

Leltári szám: II-2155

\section{TERENTIANVS TRB}

Kat. 23. Bélyeges tégla töredéke, later.

Bélyeg: T]EREN[TI]ANVS TRB

Méret: $18,8-33$ x 23,3-31 x 7,6 cm

Leltári szám: II-2987

\section{LEG I AD bélyeg és töredékei:}

Kat. 24. Bélyeges tégla töredéke, tegula.

A LEG I AD bélyeget tabula ansata keretelés határolja.

Méret: v. $3 \mathrm{~cm}$

Leltári szám: II-2862

Kat. 25. Bélyeges tégla töredéke, tegula?

Bélyeg: csak egy D betű őrzödött meg.

Méret: v. 2,6 cm

Leltári szám: II-3028

Kat. 26. Bélyeges tégla töredéke, tegula.

Bélyeg: LEG] I AD tabula ansata keretelésben. A keretelés alsó része illetve a $G$ betű részlegesen őrzödött meg.

Méret: v. 0,3-2,8 cm

Leltári szám: II-3024

Kat. 27. Bélyeges tégla töredéke, tegula?

Bélyeg: L]EG I AD - az L és D betűk részlegesen őrződtek meg.

Méret: v. 2,5 cm

Leltári szám: II-2932 
Kat. 28. Bélyeges tégla töredéke, tegula.

Bélyeg rossz megőrzödésű: ]AD - tabula ansata keretben

Méret: v. 3,2 cm

Leltári szám: II-2867

Kat. 29. Bélyeges tégla töredéke, imbrex?

A bélyeg felszíne nagyon sérült csak a L]EG I [ betűk töredéke vehető ki.

Méret: v. $1,8 \mathrm{~cm}$

Leltári szám: II-2903

Kat. 30. Bélyeges tégla töredéke, later.

Bélyeg: LEG I[ - tabula ansata? keretelésben. A betűk között interpunkciók ismerhetők fel. A bélyeg felszíne rossz megőrződésű.

Méret: v. 6,5 cm

Leltári szám: II-2964

Kat. 31. Bélyeges tégla töredéke, tegula.

Bélyeg: LEG I AD.

Méret: v. 3,3 cm

Leltári szám: II-2225

Kat. 32. Bélyeges tégla töredéke, tegula.

Bélyeg: LEG I A[ - Az E, G és A betűk csak részlegesen őrződtek meg.

Méret: v. 2,7 cm

Leltári szám: II-2996

Kat. 33. Bélyeges tégla töredéke, tegula.

Bélyeg: LEG I AD - tabula ansata keretelésben. A bélyeg felszíne több helyen sérült, így a keretelés eleje is hiányzik.

Méret: v. 2,3-2,7 cm

Leltári szám: II-2208

Kat. 34. Bélyeges téla töredéke, tegula?

Bélyeg: LEG I AD - A D betű fordítva és csak részlegesen őrzödött meg.

Méret: v. $4 \mathrm{~cm}$

Leltári szám: II-2226

Kat. 35. Bélyeges tégla töredéke, tegula.

Bélyeg: ]AD - tabula ansata keretelésben. Csak a betűk alsó részei őrződtek meg.

Méret: v. $3 \mathrm{~cm}$

Leltári szám: II-2856
Kat. 36. Bélyeges tégla töredéke, imbrex.

Bélyeg: LEG I AD - a felszín több helyen sérült.

Méret: v. $1,8 \mathrm{~cm}$

Leltári szám: II-2826

Kat. 37. Bélyeges tégla töredéke, tegula?

Bélyeg: ]D - tabula ansata? keretelésben.

Méret: v. 2,7 cm

Leltári szám: II-2926

Kat. 38. Bélyeges tégla töredéke, tegula.

Bélyeg: ] I AD [ - a felszín több helye sérült.

Méret: 8 × $14,8 \times 3 \mathrm{~cm}$

Leltári szám: II-2226

Kat. 39. Bélyeges tégla töredéke, imbrex.

Bélyeg: ]D - tabula ansata keretben.

Méret: v. 2,1-2,3 cm

Leltári szám: II-2178

Kat. 40. Bélyeges tégla töredéke, tegula.

Bélyeg: ] I AD - a keret alja nem vehető ki. Az I betű után mintha egy háromszög alakú interpunkció volna.

Méret: 14,8 x 12 × 3-3,2 cm

Leltári szám: II-2855 - áthúzva, II-3010

Kat. 41. Bélyeges tégla töredéke, imbrex.

Bélyeg: ]EG I AD - tabula ansata keretben. A keret felső része nem vehető ki. A felszín több helyen sérült.

Méret: 8 x 13,4 x 2,2-2,4 cm

Leltári szám: II-2829 vagy 2899 - elmosódott

Kat. 42. Bélyeges tégla töredéke, imbrex.

Bélyeg: LEG I AD - tabula ansata keretben. A

$\mathrm{D}$ betű fordítva van.

Méret: v. 2,1-2,5 cm

Leltári szám: II-2231

Kat. 43. Bélyeges tégla töredéke, tegula.

Bélyeg: L]EG I AD - profilált keretben.

Méret: v. 2,2-2,3 cm

Leltári szám: II-2484? - elmosódott

Kat. 44. Bélyeges tégla töredéke, imbrex?

Bélyeg: ]EG I AD - tabula ansata keretben. Az

E csak részlegesen őrzödött meg.

Méret: v. $2 \mathrm{~cm}$

Leltári szám: II-2922 
Kat. 45. Bélyeges tégla töredéke, imbrex.

Bélyeg: ]AD - a felszín több helyen sérült.

Méret: v. 2,3 cm

Leltári szám: II-3036

Kat. 46. Bélyeges tégla töredéke, imbrex.

Bélyeg: LE] I AD - nehezen kivehető, mivel a felszínét habarcs borítja. Talán tabula ansata keretelésben lehetett a bélyeg.

Méret: v. 2-3 cm

Leltári szám: II-2176

Kat. 47. Bélyeges tégla töredéke, tegula.

Bélyeg: LEG] I AD.

Méret: v. 2,7-2,8 cm

Leltári szám: II-2216?

Kat. 48. Bélyeges tégla töredéke, imbrex.

Bélyeg: LEG I AD - tabula ansata keretben. A bélyeg felső határa és lezárása nem ismerhető fel.

Méret: 29,2 x 14 x 2,3 cm

Leltári szám: nincs

Kat. 49. Bélyeges tégla töredéke, tegula.

Bélyeg: ]D - tabula ansata keretben.

Méret: v. 3,9-4 cm

Leltári szám: nincs

Kat. 50. Bélyeges tégla töredéke, imbrex.

Bélyeg: LEG I AD - tabula ansata keretben.

Méret: 37,5 x 16,8 x 2,4-2,6 cm

Leltári szám: nincs

Kat. 51. Bélyeges tégla töredéke, tegula.

Bélyeg: LEG I AD - tabula ansata keretben. Néhány betủ nagyon töredékesen őrzödött meg.

Méret: v. 2,7-3,5 cm

Leltári szám: nincs

Kat. 52. Bélyeges tégla töredéke, tegula.

Bélyeg: L]EG I [A- E, I és A betűk csak töredékesen őrződtek meg.

Méret: 29 × 24 x 3-3,2 cm

Leltári szám: nincs

Kat. 53. Bélyeges tégla töredéke, imbrex.

Bélyeg: LEG I AD - tabula ansata keretben. A bélyeg több helyen sérült.

Méret: 23,3 x 14 x 2-2,2 cm

Leltári szám: II-2156? - kopott
Kat. 54. Bélyeges tégla töredéke, tegula.

Bélyeg: ]D - részleges

Méret: $25,5 \times 24$ x 4-4,2 cm

Leltári szám: II-2943? - kopott

Kat. 55. Bélyeges tégla töredéke, imbrex.

Bélyeg: LEG I[ - tabula ansata keretben. Az I csak részlegesen őrzödött meg.

Méret: v. 2,3-2,5 cm

Leltári szám: II-2160

Kat. 56. Bélyeges tégla töredéke, tegula.

Bélyeg: LE]G I A[ - a felszíne több helyen sérült. Az A betű csak részlegesen őrzödött meg.

Méret: v. 3-3,2 cm

Leltári szám: nincs

Kat. 57. Bélyeges tégla töredéke, tegula.

Bélyeg: LEG I AD - tabula ansata keretben?

Méret: 30,2 x 29,6 x 3,5-4,2 cm

Leltári szám: nincs

Kat. 58. Bélyeges tégla töredéke, tegula.

Bélyeg: L]EG I AD. Az E betű csak részlegesen őrzödött meg. A keretelés felső része hiányzik

Méret: v. 3-3,5 cm

Leltári szám: nincs

Kat. 59. Bélyeges tégla töredéke, later.

Bélyeg: LEG I AD - tabula ansata keretben.

Méret: 41,4 x 39 x 6,2-7,5 cm

Leltári szám: nincs

Kat. 60. Bélyeges tégla, hypocaustum része, kör alakú.

Bélyeg: LEG I AD - tabula ansata keretben.

Méret: á. 22,5, v. 8-8,5 cm

Leltári szám: II-2965

Kat. 61. Bélyeges tégla töredéke, later.

Bélyeg: LEG I A[ - felszínét habarcs borítja.

Méret: v. 8,6-9,4 cm

Leltári szám: 2802? nagyon halvány

Kat. 62. Bélyeges tégla töredéke, later.

Bélyeg: LEG I AD - tabula ansata keretelésben. Az felirat elején lévő ansát egy stilizált fenyőfa ág tölt ki, míg a végén lévő ansát egy stilizált koszorú ékít. A felszín több helyen sérült. A LEG I és $\mathrm{AD}$ szavakat háromszög alakú interpunkciók választanak el.

Méret: v. $8 \mathrm{~cm}$

Leltári szám: nincs 
Kat. 63. Bélyeges tégla, tubulus.

Bélyeg: ]AD - a felszínét habarcs fedi. Csak a betűk sziluetjei vehetők ki.

Méret: 31 x 13 x 16, v. $1,5-2 \mathrm{~cm}$

Leltári szám: II-3014

Kat. 64. Bélyeges tégla, hypocaustum.

Bélyeg: LEG I AD - tabula ansata keretben.

Méret: á. 22,6 cm, v. 7,8-8,8 cm

Leltári szám: II-2965

Kat. 65. Bélyeges tégla töredéke, imbrex.

Bélyeg: LEG I AD - a felszíne elég kopott, pár betű csak részlegesen ismerhető fel.

Méret: $49,2 \times 18,3 \times 1,8 \mathrm{~cm}$

Leltári szám: nincs

Kat. 66. Bélyeges tégla töredéke, tegula.

Bélyeg: LEG I AD - tabula ansata keretben. A felszíne több helyen sérült.

Méret: v. 3-3,2 cm

Leltári szám: II-2905? - kopott

\section{LEG I ADI}

Kat. 67. Bélyeges tégl töredéke, tegula.

Bélyeg: LEG I A]DI.

Méret: 8-12 x 16 x $3 \mathrm{~cm}$

Leltári szám: II-2871

Kat. 68. Bélyeges tégla töredéke, imbrex.

Bélyeg: L]EG I ADI

Méret: 10,7 x 12,5 x 2,3 cm

Leltári szám: II-2925

Kat. 69. Bélyeges tégla töredéke, tegula.

Bélyeg: LE]G I ADI[ -a felszín több helyen sérült.

Méret: v. 3,7 cm

Leltári szám: II-2837

Kat. 70. Bélyeges tégla töredéke, tegula.

Bélyeg: L]EG I VDI.

Méret: v. 2,8-3 cm

Leltári szám: II-2137

Kat. 71. Bélyeges tégla töredéke, imbrex.

Bélyeg: L]EG I ADI.

Méret: v. $2 \mathrm{~cm}$

Leltári szám: II-2204
Kat. 72. Bélyeges tégla töredéke, tegula.

Bélyeg: LEG I ADI - tabula ansata keretben.

Méret: 31 x 21 x 3-4,5 cm

Leltári szám: nincs

Kat. 73. Bélyeges tégla töredéke, tegula.

Bélyeg: LEG I] ADI - nagyon rossz megőrzödésű, alíg olvasható.

Méret: v. 2,7 cm

Leltári szám: nincs

Kat. 74. Bélyeges tégla töredéke, tegula.

Bélyeg: ]DI -a felszíne nagyon sérült. A betűk csak részlegesen őrződtek meg.

Méret: 31 x 27 x 3-3,4 cm

Leltári szám: nincs

Kat. 75. Bélyeges tégla töredéke, tegula.

Bélyeg: LEG] I VDI - nagyon halvány szinte olvashatatlan.

Méret: 32 x 28 x 3,8-4,2 cm

Leltári szám: II-2164

Kat. 76. Bélyeges tégla töredéke, tegula.

Bélyeg: LE]G I VDI - a felszín több helyen sérült. Rossz megőrzödésű, szinte kivehetetlen a bélyeg.

Méret: 48 x 43 x 2,8-3,9 cm

Leltári szám: nincs

Kat. 77. Bélyeges tégla töredéke, tegula.

Bélyeg: LEG I ADI - tabula ansata keretben. A bélyeg felszíne több helyen sérült. Az A és I betük csak részlegesen őrződtek meg.

Méret: v. 2,8-3 cm

Leltári szám: II-2198

\section{LEG I ADIE}

Kat. 78. Bélyeges tégla töredéke, imbrex.

Rossz megőrzödésủ bélyeg: ] VDIE.

Méret: 8-8,5 x 13,5 x $2 \mathrm{~cm}$

Leltári szám: II-2266? Nagyon halvány

Kat. 79. Bélyeges tégla töredéke, tegula?

Bélyeg: ]DIE - rossz megőrzödésű

Méret: v. 3,2 cm

Leltári szám: II-2218 
Kat. 80. Bélyeges tégla töredéke, imbrex.

Bélyeg: ]VDIE.

Méret: $13,5-14,2 \times 12 \times 2 \mathrm{~cm}$

Leltári szám: II-2207

Kat. 81. Bélyeges tégla töredéke, imbrex.

Bélyeg: LE]G I ADIE - a felszín több helyen sérült.

Méret: 17 x 11 x 2,3-2,4 cm

Leltári szám: II-2344? - kopott, alíg olvasható

Kat. 82. Bélyeges tégla töredéke, tegula?

Bélyeg: ]I VDIE - a felszínt üledék borítja.

Méret: $3,2 \mathrm{~cm}$

Leltári szám: II-3005

Kat. 83. Bélyeges tégla töredéke, tegula.

Bélyeg: ]G I VDIE - a felszín több helyen sérült. A G betű csak töredékesen őrzödött meg.

Méret: v. $3 \mathrm{~cm}$

Leltári szám: II-2881

Kat. 84. Bélyeges tégla töredéke, imbrex.

Bélyeg: ] I VDIE - a felszín több helyen sérült.

Méret: v. 1,9 cm

Leltári szám: II-2860

Kat. 85. Bélyeges tégla töredéke, tegula.

Bélyeg: ] I VDIE - a felszín több helyen sérült.

Méret: v. 2,6-3 cm

Leltári szám: II-2984

Kat. 86. Bélyeges tégla töredéke, tegula.

Bélyeg: ]G I ADIE - a G csak részlegesen őrzödött meg.

Méret: 13,5 x 12,5 x 2,8-3,4 cm

Leltári szám: II-2902

Kat. 87. Bélyeges tégla töredéke, imbrex.

Bélyeg: ]VDIE - a felszín több helyen sérült. $\mathrm{Az} \mathrm{V}$ csak részlegesen őrzödött meg.

Méret: 21,5 x 14 x 1,8-2 cm

Leltári szám: II-2199

Kat. 88. Bélyeges tégla töredéke, tegula.

Bélyeg: ]VDIE - a felszínt részlegesen habarcs borítja.

Méret: v. 3,2 cm

Leltári szám: II-2860
Kat. 89. Bélyeges tégla töredéke, imbrex.

Bélyeg: L]EG I ADIE - a felszín több helyen sérült.

Méret: v. $2 \mathrm{~cm}$

Leltári szám: II-3018

Kat. 90. Bélyeges tégla töredéke, imbrex.

Bélyeg: ]VDIE - a keretelés felső része nem kivehető.

Méret: v. $2,1 \mathrm{~cm}$

Leltári szám: II-2945

Kat. 91. Bélyeges tégla töredéke, tegula.

Bélyeg: LEG I ADIE - a keretelés alja és eleje hiányzik. Az LEG betűk csak részlegesen őrződtek meg.

Méret: v. 2,8 cm

Leltári szám: II-2233

Kat. 92. Bélyeges tégla töredéke, later?

Bélyeg: ]ADIE.

Méret: v. 4,5 cm

Leltári szám: II-2914

Kat. 93. Bélyeges tégla töredéke, imbrex.

Bélyeg: LE]G I ADIE -a keretelés alsó része nem ismerhető fel.

Méret: v. $2 \mathrm{~cm}$

Leltári szám: II-2154

Kat. 94. Bélyeges tégla töredéke, tegula.

Bélyeg: ADIE - a keret alsó része nem kivehető. Az A csak részlegesen őrzödött meg.

Méret: v. 3-3,6 cm

Leltári szám: nincs

Kat. 95. Bélyeges tégla töredéke, imbrex.

Bélyeg: ]D[I]E

Méret: v. $2 \mathrm{~cm}$

Leltári szám: II-2900?

Kat. 96. Bélyeges tégla töredéke, tegula.

Bélyeg: L]EG I [A]DIE. A felszíne több helyen sérült. $\mathrm{Az} A, \mathrm{D}, \mathrm{I}$ és $\mathrm{E}$ betük csak részlegesen őrződtek meg.

Méret: v. 2,3-3 cm

Leltári szám: II-2203 áthúzva, alatta II-4318 
Kat. 97. Bélyeges tégla töredéke, tegula.

Bélyeg: ]DIE

Méret: v. 3,4-3,8 cm

Leltári szám: nincs

Kat. 98. Bélyeges tégla töredéke, tegula.

Bélyeg: LE]G I VDIE - a felszínét habarcs fedi, ezért csak részlegesen ismerhetők fel a betűk.

Méret: 24,4 x 35 x 3,8-4,6 cm

Leltári szám: nincs

Kat. 99. Bélyeges tégla töredéke, hypocaustum tégla.

Bélyeg: LEG I ADIE - a felszínt habarcs fedi, ezért a betűk csak töredékesen ismerhetőek fel. Méret: 17,7 x 16 x 5,3-5,5 cm

Leltári szám: nincs

Kat. 100. Bélyeges tégla töredéke, imbrex.

Bélyeg: LEG I] ADIE - a felszín több helyen sérült.

Méret: 23,7 x 15 x 2-2,5 cm

Leltári szám: nincs

Kat. 101. Bélyeges tégla töredéke, tegula.

Bélyeg: LEG I AD]IE - felszíne több helyen sérült.

Méret: 30,5 x 33 x 2,53 cm

Leltári szám: nincs

Kat. 102. Bélyeges tégla töredéke, tegula.

Bélyeg: L]EG I ADIE - a felszín több helyen sérült. A keretelés alsó része nem kivehető.

Méret: v. 3,3-3,7 cm

Leltári szám: nincs

Kat. 103. Bélyeges tégla töredéke, later.

Bélyeg: LEG I ADIE - a felszíne több helyen sérült.

Méret: 20,5 x 18 x 4,8-5,5 cm

Leltári szám: II-2998

Kat. 104. Bélyeges tégla, hypocaustum.

Bélyeg: LEG I ADIE - pár betű csak részlegesen ismerhető fel, mivel felszínét habarcs fedi.

Méret: 20 x 20 x 6,1-6,4 cm

Leltári szám: II-2227

Kat. 105. Bélyeges tégla töredéke, imbrex.

Bélyeg: LEG I ADIE

Méret: v. 2,5 cm

Leltári szám: II-2855
Kat. 106. Bélyeges tégla töredéke, imbrex.

Bélyeg: LEG I] ADIE

Méret: v. 1,5-1,8 cm

Leltári szám: II-2195

\section{LEG P ADI}

Kat. 107. Bélyeges tégla töredéke, tegula?

Bélyeg: LEG P ADI - tabula ansata keretelésben.

Méret: v. 3,7 cm

Leltári szám: II-2220? - kopott

\section{LEG I AR?}

Kat. 108. Bélyeges tégla töredéke, hypocaustum része.

Bélyeg: L]EG I AR? - tabula ansata keretben? A felszín nagyon rossz megőrződésű, habarcs borítja. A LEG I A szavak között kör alakú interpunkciók ismerhetők fel.

Méret: átmérő: $23 \mathrm{~cm}$, v. 5,7-6,2 cm

Leltári szám: II-2200

\section{LEG I A PF}

Kat. 109. Bélyeges tégla, hypocaustum tégla.

Bélyeg: LEG I A PF - tabula ansata keretben? A felszínét habarcs fedi a betűk nehezen felismerhetőek.

Méret: á. $23 \mathrm{~cm}$, v. 7,5-8,5 cm

Leltári szám: II-2946? Nagyon kopott

Kat. 110. Bélyeges tégla, hypocaustum tégla.

Bélyeg: LEG I A PF - tabula ansata keretben. A felszínét habarcs borítja.

Méret: á. 23,5 cm, v. 7,8-8,5 cm

Leltári szám: II-2966

Kat. 111. Bélyeges tégla, hypocaustum tégla.

Bélyeg: LEG I] A PF - tabula ansata keretben? A felszínét habarcs fedi, nehezen felismerhetők az egyes betűk.

Méret: á. 23,3 cm, v. 7,8-8 cm

Leltári szám: II-2950

\section{I A PF ANT}

Kat. 112. Bélyeges tégla, tegula.

Bélyeg: L I A PF ANT - ANT ligatúra. A felszínét részlegesen meszes réteg fedi.

Méret: 55 x 53 x 2,5 cm

Leltári szám: nincs 


\section{LEG I AD PF}

Kat. 113. Bélyeges tégla töredéke, later.

Bélyeg: LEG] I AD PF - a P és F betűk csak részlegesen őrződtek meg.

Méret: v. $5,5 \mathrm{~cm}$

Leltári szám: II-4321

Kat. 114. Bélyeges tégla töredéke, later?

Bélyeg: LEG] I AD [PF?] - tabula ansata keretelésben. A P? és F? betűkből csak a szár őrzödött meg.

Méret: v. $5 \mathrm{~cm}$

Leltári szám: II-2235

Kat. 115. Bélyeges tégla töredéke, tegula?

Bélyeg: LEG I AD P[F] - egyszerü keretben.

Méret: 18 x 18,4 x 2,7 cm

Leltári szám: II-2141

Kat. 116. Bélyeges tégla töredéke, tegula?

Bélyeg: LEG I]AD PF - tabula ansatában. Rossz megőrzödésű bélyeg.

Méret: 9 x 12,4 x 3,1 cm

Leltári szám: II-4320

Kat. 117. Bélyeges tégla töredéke, tegula.

Bélyeg: LEG I AD PF - tabula ansata keretelésben.

Méret: v. 3,5-3,7 cm

Leltári szám: II-2920

Kat. 118. Bélyeges tégla töredéke, tegula.

Bélyeg: LEG I AD[.

Méret: 19 x 18 × $3 \mathrm{~cm}$

Leltári szám: II-2198

Kat. 119. Bélyeges tégla töredéke, tegula.

Bélyeg: LEG] I AD PF - tabula ansata keretben?

Méret: v. 3,2 cm

Leltári szám: II-2140

Kat. 120. Bélyeges tégla töredéke, tegula.

Bélyeg: LEG I AD PF - A PF csak részlegesen őrzödött meg.

Méret: v. 2,8-3 cm

Leltári szám: II-2845
Kat. 121. Bélyeges tégla töredéke, tegula?

Bélyeg: LEG I AD PF - tabula ansata keretben, az eleje sérült.

Méret: v. 3,6 cm

Leltári szám: II-2157

Kat. 122. Bélyeges tégla töredéke, later.

Bélyeg: LEG I A[D] PF. A D betüt habarcs fedi.

Méret: $27,2 \times 25 \times 5-5,8 \mathrm{~cm}$

Leltári szám: II-2212

Kat. 123. Bélyeges tégla töredéke, tegula.

Bélyeg: LE]G I AD PF

Méret: 28,8 x 22,5 x 2,4-3,4 cm

Leltári szám: nincs

\section{LEG I ADI PF?}

Kat. 124. Bélyeges tégla töredéke, tegula.

Bélyeg: LEG I ADI II - az utolsó két betű csak részlegesen őrzödött meg, talán PF? A felszíne több helyen sérült.

Méret: 43 x 48,8 x 3-3,6 cm

Leltári szám: nincs

\section{LEG I ADI PF AN}

Kat. 125. Bélyeges tégla töredéke, tegula.

Bélyeg: LEG I ADI PF AN[T? - tabula ansata keretben.

Méret: v. 3,4-3,8 cm

Leltári szám: nincs

Kat. 126. Bélyeges tégla töredéke, tegula.

Bélyeg: LEG] I ADI PF AN - a felszín több helyen sérült. AN ligatúra.

Méret: v. 3,5 cm

Leltári szám: nincs

\section{LEG I A PF AN}

Kat. 127. Bélyeges tégla töredéke, tegula.

Bélyeg: LEG I] A PF AN - AN ligatúra.

Méret: v. 2,4 cm

Leltári szám: II-2139

Kat. 128. Bélyeges tégla töredéke, tegula.

Bélyeg: LEG I A P - tabula ansata keretben. A bélyeg több helyen sérült.

Méret: v. 2,3-2,5 cm

Leltári szám: II-2868 


\section{LEG I AD PF AAN}

Kat. 129. Bélyeges tégla töredéke, hypocaustum része.

Bélyeg: LEG I [AD] PF AAN - a felszín több helyen sérült, részlegesen habarcs borítja

Méret: 16,5 x 20,5 x 6,7-7,1 cm

Leltári szám: nincs

\section{LEG I ADI PF AANT}

Kat. 130. Bélyeges tégla, hypocaustum.

Bélyeg: LEG I ADI PF AANT - AN ligatúra. A felszíne nagyon kopott, pár betű csak nagyon halványan látszik.

Méret: 20 x 20 x 7,8-8 cm

Leltári szám: II-2966

\section{LEG[}

Kat. 131. Bélyeges tégla töredéke, tegula.

Bélyeg: LEG[ - Az L és E betűk között egy háromszög formájú interpunkció található.

Méret: v. $3 \mathrm{~cm}$

Leltári szám: II-3029

Kat. 132. Bélyeges tégla töredéke, tegula.

Bélyeg: LE[ - tabula ansata keretben. Felszíne több helyen sérült.

Méret: 13 x 16,3 x 2,8 cm

Leltári szám: nincs

Kat. 133. Bélyeges tégla töredéke, later.

Bélyeg: LEG[ - a felszín nagyon rossz megőrzödésű, habarcs borítja.

Méret: 29,8 x 20,5 x 6,5-6,9 cm

Leltári szám: nincs

Kat. 134. Bélyeges tégla töredéke, tegula.

Bélyeg: LEG[

Méret: 25,5 x 23,8 x 3,3-3,9 cm

Leltári szám: nincs

\section{LEG I AD - retrograd bélyeg töredékes}

Kat. 135. Bélyeges tégla töredéke, tegula.

A LEG I A[ retrográd bélyeget tabula ansata keretelés határol.

Méret: $14-15$ x 15-19 x 3,2 cm

Leltári szám: II-2923
Kat. 136. Bélyeges tégla töredéke, imbrex.

Felszín repedezett. Retrográd bélyeg: L]EG I A[D. A D betű csak részlegesen őrzödött meg.

Méret: v. 1,7-2,2 cm

Leltári szám: II-2838

Kat. 137. Bélyeges tégla töredéke, imbrex.

Tabula ansata keretelésben LEG I AD retrográd bélyeg. Az A és $\mathrm{D}$ betűk csak részlegesen őrződtek meg.

Méret: v. 2,6 cm

Leltári szám: II-2236

Kat. 138. Bélyeges tégla töredéke, tegula.

Retrográd bélyeg töredéke: LEG I V[.

Méret: 12,5-20,9 x 13,6 x 3,6 cm

Leltári szám: II-2211 áthúzva, II-4323

Kat. 139. Bélyeges tégla töredéke, imbrex.

Retrográd bélyeg: LEG I AD[ tabula ansata keretelésben (csak az eleje maradt meg).

Méret: v. $2 \mathrm{~cm}$

Leltári szám: II-2865

Kat. 140. Bélyeges tégla töredéke, imbrex.

Retrográd bélyeg: L]EG I V[.

Méret: v. $1,5 \mathrm{~cm}$

Leltári szám: II-2924

Kat. 141. Bélyeges tégla töredéke, tegula.

Retrográd bélyeg: LEG I VD. A felszínét kruszta borítja.

Méret: v. 3,3 cm

Leltári szám: II-3032

Kat. 142. Bélyeges tégla töredéke, tegula.

Retrográd bélyeg: LEG I AD - tabula ansata keretelésben. A felszínét részlegesen kruszta borítja.

Méret: $21-29$ x 30 x 3,2 cm

Leltári szám: II-2214

Kat. 143. Bélyeges tégla töredéke, imbrex.

Retrográd bélyeg: LEG I A[ - rossz megőrzödésủ, talán tabula ansata keretelésben?

Méret: $19-20$ x 12-13 x 2,2 cm

Leltári szám: II-2191

Kat. 144. Bélyeges tégla töredéke.

Retrográd szinte olvashatatlan bélyeg: L[E]G 
[I] V[ - az E, G és V betűk csak részlegesen őrződtek meg.

Méret: v. $3,2 \mathrm{~cm}$

Leltári szám: II-2179

Kat. 145. Bélyeges tégla töredéke, tegula.

Bélyeg: LEG I AD - retrográd, tabula ansata keretben, melynek az L betủ előtti része csak részlegesen őrzödöt meg.

Méret: v. $4 \mathrm{~cm}$

Leltári szám: II-3012

Kat. 146. Bélyeges tégla töredéke.

Bélyeg: LEG I AD - retrográd, tabula ansata keretlésben. A betűk csak részlegesen őrződtek meg.

Méret: $10-10,5 \times 14,5-15 \times 3 \mathrm{~cm}$

Leltári szám: II-2173? - nagyon halvány

Kat. 147. Bélyeges tégla töredéke, tegula.

Bélyeg: [L]EG I AD - retrográd. Az E és a D betűk csak részlegesen őrződtek meg.

Méret: 9 x 11,8 x $3,2 \mathrm{~cm}$

Leltári szám: II-2858

Kat. 148. Bélyeges tégla töredéke, tegula.

Bélyeg: L]EG I AD - retrográd.

Méret: v. 3,2 cm

Leltári szám: II-2202

Kat. 149. Bélyeges tégla töredéke, tegula?

Bélyeg: LEG I VD - retrográd. Az L, E és D betűk csak részlegesen őrződtek meg.

Méret: v. $3,8 \mathrm{~cm}$

Leltári szám: II-3030

Kat. 150. Bélyeges tégla töredéke, tegula.

Bélyeg: LEG I VD - retrográd.

Méret: 19 x 12 x 2,6 cm

Leltári szám: II-2224

Kat. 151. Bélyeges tégla töredéke, imbrex.

Bélyeg: LEG [I] V - retrográd. A felszín nagyon rossz megőrzödésű.

Méret: v. $1,8 \mathrm{~cm}$

Leltári szám: II-2968

Kat. 152. Bélyeges tégla töredéke, imbrex.

Bélyeg: LEG I A[ - retrográd. A felszín több helyen sérült.

Méret: v. 1,6-1,8 cm

Leltári szám: II-3019
Kat. 153. Bélyeges tégla töredéke, tegula.

Bélyeg: LEG I AD - retrográd, tabula ansata keretben. A D betű csak részlegesen őrzödött meg.

Méret: v. 3-3,8 cm

Leltári szám: II-2193

Kat. 154. Bélyeges tégla töredéke, tegula.

Bélyeg: LEG I V[ - tabula ansata? keretben. A keretelés felső része nem ismerhető fel. A felszín sérült, a bélyeg nagyon rossz megőrzödésü.

Méret: $4-4,2 \mathrm{~cm}$

Leltári szám: II-2807

Kat. 155. Bélyeges tégla töredéke, tegula?

Bélyeg: ]AD - retrográd, tabula ansata keretben. Az A csak részlegesen őrzödöt meg.

Méret: v. 3-3,9 cm

Leltári szám: II-2223

Kat. 156. Bélyeges tégla töredéke, tegula.

Bélyeg: LEG I A[ - retrográd, tabula ansata keretben. $\mathrm{Az} \mathrm{A}$ betű csak részlegesen őrzödött meg. A felszín több helyen sérült.

Méret: v. 3-3,2 cm

Leltári szám: II-3001

Kat. 157. Bélyeges tégla töredéke, tegula?

Bélyeg: LEG I AD - retrográd, tabula ansata keretben. A felszín több helyen sérült. A D betű csak részlegesen őrzödött meg.

Méret: v. 2,3-2,8 cm

Leltári szám: II-2889?

Kat. 158. Bélyeges tégla töredéke, imbrex.

Bélyeg: LEG I A[ - retrográd. A felszín több helyen sérült.

Méret: v. $2,5 \mathrm{~cm}$

Leltári szám: II-2230

Kat. 159. Bélyeges tégla töredéke, imbrex.

Bélyeg: LEG I A[ - retrográd. A felszín több helyen sérült.

Méret: v. 1,8-2,1 cm

Leltári szám: II-2201

Kat. 160. Bélyeges tégla töredéke, imbrex.

Bélyeg: LEG I AD - retrográd. A keretelés felső és jobb oldali része nem kivehető. A felszín több helyen sérült. 
Méret: v. 2,2 cm

Leltári szám: II-2172

Kat. 161. Bélyeges tégla töredéke, tegula.

Bélyeg: LEG I AD - retrográd, tabula ansata keretben. A keret felső része nem ismerhető fel.

Méret: v. $3,8 \mathrm{~cm}$

Leltári szám: II-2164

Kat. 162. Bélyeges tégla töredéke, tegula.

Bélyeg: LEG I A[ - retrográd, tabula ansata keretben. A felszíne több helyen sérült.

Méret: v. 2,4 cm

Leltári szám: II-2894

Kat. 163. Bélyeges tégla töredéke, tegula?

Bélyeg: LEG I AD - retrográd.

Méret: v. 3,4 cm

Leltári szám: II-2324? - halvány

Kat. 164. Bélyeges tégla töredéke, imbrex.

Bélyeg: LEG I] AD - retrográd. Háromszög záródású a keret.

Méret: 16 x 12,5 x 2,2 cm

Leltári szám: II-2863

Kat. 165. Bélyeges tégla töredéke, tegula.

Bélyeg: LEG I AD - retrográd, tabula ansata keretben.

Méret: v. 3,8 cm

Leltári szám: II-2222

Kat. 166. Bélyeges tégla töredéke, imbrex.

Bélyeg: LEG] I AD - retrográd, tabula ansata keretben?

Méret: v. 2,2 cm

Leltári szám: nincs

Kat. 167. Bélyeges tégla töredéke, imbrex.

Bélyeg: LEG I A[ - retrográd.

Méret: 26,6x 17 x 1,6-2,2 cm

Leltári szám: nincs

Kat. 168. Bélyeges tégla töredéke, imbrex.

Bélyeg: LEG I AD - retrográd. Az L, E, A és D csak részlegesen őrzödött meg.

Méret: 33 x 17 x 2-2,8 cm

Leltári szám: II-3020
Kat. 169. Bélyeges tégla töredéke, hypocaustum?

Bélyeg: LEG I AD - retrográd. A felszínét habarcs borítja.

Méret: 15,5 x 13,8 x 3,5-5 cm

Leltári szám: nincs

Kat. 170. Bélyeges tégla töredéke, tegula.

Bélyeg: LEG I A] - retrográd, tabula ansata keretben?

Méret: 43 x 23,5 x 3,5-4 cm

Leltári szám: nincs

Kat. 171. Bélyeges tégla töredéke, tegula.

Bélyeg: LEG I AD[ - a felszíne több helyen sérült. Az L betű csak részlegesen őrzödött meg.

Méret: v. 3,5-3,8 cm

Leltári szám: II-2234

Kat. 172. Bélyeges tégla töredéke, later.

Bélyeg: LE]G [I] AD - retrográd. A felszín több helyen sérült, részlegesen a felszínt meszes habarcsos réteg fedi.

Méret: v. 5,2-5,6 cm

Leltári szám: nincs

Kat. 173. Bélyeges tégla töredéke, tegula.

Bélyeg: LEG I AD - retrográd, tabula ansata keretben? részlegesen meszes üledék található rajta. A felszíne nagyon kopott.

Méret: 40,5 x 40 x 3,3-4 cm

Leltári szám: nincs

Kat. 174. Bélyeges tégla töredéke, imbrex.

Bélyeg: LE]G I AD - retrográd.

Méret: v. 2-2,3 cm

Leltári szám: II-2202? Kopott

Kat. 175. Bélyeges tégla töredéke, tegula.

Bélyeg: LEG I A[ - retrográd. A betük nehezen kivehetők, mivel a felszínét részlegesen meszes réteg fedi.

Méret: v. $3 \mathrm{~cm}$

Leltári szám: II-4532? - kopott

\section{LEG I ADI - retrograd}

Kat. 176. Bélyeges tégla töredéke, imbrex.

Nehezen kivehető retrográd bélyeg: L]EG I VDI.

Méret: $16,5-24,3$ x 10-11 x 2,3 cm

Leltári szám: II-4317 
Kat. 177. Bélyeges tégla töredéke, tegula.

Bélyeg: ]EG I ADI - retrográd, tabula ansata keretben.

Méret: v. 3-4 cm

Leltári szám: II-2187

Kat. 178. Bélyeges tégla töredéke, tegula.

Bélyeg: ]G I ADI[ - retrográd.

Méret: 8,8 x 21 x 2,4-3,2 cm

Leltári szám: II-2809

Kat. 179. Bélyeges tégla töredéke, imbrex.

Bélyeg: ]I ADI - retrográd. A G és I betűk csak részlegesen őrződtek meg. A felszín több helyen sérült.

Méret: v. 2-2,5 cm

Leltári szám: II-2205

Kat. 180. Bélyeges tégla töredéke, tegula.

Bélyeg: LEG I ADI - retrográd. A felszíne több helyen sérült.

Méret: v. 2,8 cm

Leltári szám: II-2196

Kat. 181. Bélyeges tégla töredéke, imbrex.

Bélyeg: LEG] I ADI[ - retrográd. A felszíne több helyen sérült.

Méret: 15,5 x 13,2 x 2,2-2,5 cm

Leltári szám: II-2926?

Kat. 182. Bélyeges tégla töredéke, tegula.

Bélyeg: LEG I ADI - retrográd. A felszín nagyon kopott, pár betű szinte felismerhetetlen.

Méret: v. 3,4-3,7 cm

Leltári szám: nincs

Kat. 183. Bélyeges tégla töredéke, tegula.

Bélyeg: LEG I ADI - retrográd. A felszínét habarcs borítja, ezért nehezen felismerhetők az egyes betűk. A bélyeg végén egy kutya láblenyomata ismerhető fel.

Méret: v. 3,3-3,5 cm

Leltári szám: nincs

Kat. 184. Bélyeges tégla töredéke, tegula.

Bélyeg: LEG [I A]DI - retrográd. A felszín több helyen sérült. Az L, G, A, D és I betűk csak részlegesen őrződtek meg.

Méret: v. 2,5-3 cm

Leltári szám: II-2950
Kat. 185. Bélyeges tégla töredéke, tegula.

Bélyeg: LEG I ADI - retrográd. A felszín több helyen sérült. Az E, D és I betűk csak részlegesen őrződtek meg.

Méret: v. 2,5-3 cm

Leltári szám: nincs

Kat. 186. Bélyeges tégla töredéke, tegula.

Bélyeg: LEG I ADI - retrográd. A felszíne több helyen sérült. Pár betű csak részlegesen őrzödött meg.

Méret: 43 x 53,6 x 2,6-2,8 cm

Leltári szám: nincs

\section{LEG I ADIE - retrograd}

Kat. 187. Bélyeges tégla töredéke, tegula.

Retrográd bélyeg: LEG I ADIE.

Méret: v. $2,8 \mathrm{~cm}$

Leltári szám: II-2876

Kat. 188. Bélyeges tégla töredéke, tegula.

Retrográd? nagyon rossz megőrzödésű bélyeg:

] VDIE

Méret: v. 3,2 cm

Leltári szám: II-2874

Kat. 189. Bélyeges tégla töredéke, imbrex.

Bélyeg: LEG I VDIE - retrográd.

Méret: 21,2 x $12,5 \times 1,8 \mathrm{~cm}$

Leltári szám: II-2855

Kat. 190. Bélyeges tégla töredéke, imbrex.

Bélyeg: LEG I VDIE - retrográd. Az L és IE betűk csak részlegesen őrződtek meg.

Méret: v. $1,8 \mathrm{~cm}$

Leltári szám: II-2215

Kat. 191. Bélyeges tégla töredéke, tegula.

Bélyeg: LEG I ADIE - retrográd.

Méret: v. 3,2-3,3 cm

Leltári szám: II-2890?

Kat. 192. Bélyeges tégla töredéke, imbrex?

Bélyeg: LEG I] ADIE - retrográd. A felszín több helyen sérült.

Méret: 15,5 x 10 x 2,2-2,3 cm

Leltári szám: nincs 
Kat. 193. Bélyeges tégla töredéke, imbrex.

Bélyeg: LEG I A]DIE - retrográd.

Méret: v. $2 \mathrm{~cm}$

Leltári szám: nincs

Kat. 194. Bélyeges tégla töredéke, later.

Bélyeg: LEG] I ADIE? - retrográd? A felszíne nagyon rossz megőrzödésü.

Méret: 17 x 7,7 x 4-5,5 cm

Leltári szám: nincs

Kat. 195. Bélyeges tégla töredéke, imbrex.

Bélyeg: LEG I [A]DIE - retrográd. A felszíne több helyen sérült

Méret: 50 x 15,7 x 1,6-2 cm

Leltári szám: nincs

\section{LEG I AD PF - retrograd}

Kat. 196. Bélyeges tégla töredéke, imbrex?

Bélyeg: LEG I VD PF - retrográd. A tégla felszíne több helyen sérült.

Méret: $2-2,5 \mathrm{~cm}$

Leltári szám: II-2175

Kat. 197. Bélyeges tégla töredéke, tegula.

Bélyeg: Leg I AD PF - retrográd.

Méret: v. $3 \mathrm{~cm}$

Leltári szám: II-2882

Kat. 198. Bélyeges tégla töredéke, tegula.

Bélyeg: LEG I AD PF - retrográd, tabula ansa$t a$ keretben. részlegesen a bélyeget habarcs borítja.

Méret: 22,7 x 21 x 3,3-3,6 cm

Leltári szám: II-2875

Kat. 199. Bélyeges tégla töredéke, tegula.

Bélyeg: LEG I AD PF - retrográd, tabula ansata keretben? A felszíne elég rossz megőrzödésű.

Méret: 20,5 x 35 x 3-4 cm

Leltári szám: nincs

\section{LEG I AD PIF?}

Kat. 200. Bélyeges tégla, hypocaustum.

Bélyeg: LEG I AD PIF? - retrográd.

Méret: á. $22 \mathrm{~cm}$, v. 3,5-7,8 cm

Leltári szám: II-2966

\section{LEG I ADIE PF - retrograd}

Kat. 201. Bélyeges tégla töredéke, tegula.

Bélyeg: LEG I ADIE PF? - retrográd. A felszín több helyen sérült. A bélyeg rossz megőrzödésü.

Méret: 16 x 27,5 x 3-3,2 cm

Leltári szám: nincs

\section{LEG[ - retrograd}

Kat. 202. Bélyeges tégla töredéke, imbrex.

Retrográd bélyeg: LEG[

Méret: v. 2,2 cm

Leltári szám: II-2177

Kat. 203. Bélyeges tégla töredéke, imbrex.

Retrográd bélyeg: LEG[

Méret: 8-11,5 x 16,2 × $2 \mathrm{~cm}$

Leltári szám: II-2210

Kat. 204. Bélyeges tégla töredéke, imbrex?

Bélyeg: LEG[ - retrográd.

Méret: $9,5 \times 7,5 \times 2-2,2 \mathrm{~cm}$

Leltári szám: II-2161

Kat. 205. Bélyeges tégla töredéke, imbrex.

Bélyeg: LEG[ - retrográd. Az L betű csak részlegesen őrzödött meg.

Méret: 9 x 12,4 x 1,7-2 cm

Leltári szám: II-2153? - halvány, kopott

Kat. 206. Bélyeges tégla töredéke, imbrex.

Bélyeg: LEG[ - retrográd. A felszín több helyen sérült.

Méret: v. $1,8 \mathrm{~cm}$

Leltári szám: II-2181

Kat. 207. Bélyeges tégla töredéke, imbrex.

Bélyeg: LEG[ - retrográd. A felszín több helyen sérült.

Méret: v. 1,8-2 cm

Leltári szám: II-2145

Kat. 208. Bélyeges tégla töredéke, imbrex.

Bélyeg: LEG[ - retrográd. A bélyeg felső része nem látható.

Méret: v. $1,8 \mathrm{~cm}$

Leltári szám: II-2183 
Kat. 209. Bélyeges tégla töredéke, imbrex.

Bélyeg: LEG[ - retrográd.

Méret: 11 x $11,5 \times 2,2 \mathrm{~cm}$

Leltári szám: II-2184

Kat. 210. Bélyeges tégla töredéke, tegula.

Bélyeg: LEG[ - retrográd.

Méret: v. 3,4-3,8 cm

Leltári szám: II-3002

Kat. 211. Bélyeges tégla töredéke, imbrex.

Bélyeg: LEG[ - retrográd.

Méret: v. 2,2 c

Leltári szám: nincs

Kat. 212. Bélyeges tégla töredéke, tegula?

Bélyeg: LEG[ - retrográd, tabula ansata keretben.

Méret: v. 3,2-3,5 cm

Leltári szám: nincs

Kat. 213. Bélyeges tégla töredéke, tegula.

Bélyeg: LEG[ - retrográd

Méret: v. 3,2-3,5 cm

Leltári szám: II-2170

\section{LEG I[ - retrograd}

Kat. 214. Bélyeges tégla töredéke, tegula.

Bélyeg: LE[G] I [ - retrográd, nagyon rossz megőrzödésü.

Méret: v. 3,3 cm

Leltári szám: II-2877

Kat. 215. Bélyeges tégla töredéke, imbrex.

Bélyeg: LEG I [ - retrográd. Az I csak részlegesen őrzödött meg.

Méret: 11 x 9 x $1,8 \mathrm{~cm}$

Leltári szám: II-2914? - kopott

Kat. 216. Bélyeges tégla töredéke, tegula?

Bélyeg: LEG I [ - retrográd. Az I csak részlegesen őrzödött meg.

Méret: v. $4,5 \mathrm{~cm}$

Leltári szám: II-4322

Kat. 217. Bélyeges tégla töredéke, tegula.

Bélyeg: LEG I[ - retrográd, tabula ansata keretben. A tégla felszíne nagyon rossz megőrzödésü, potyog szét.

Méret: v. 3,4 cm

Leltári szám: nincs
Kat. 218. Bélyeges tégla töredéke, tegula.

Bélyeg: LEG I[ - retrográd. Tabula ansata keretben. A felszínét meszes habarcsos anyag borítja, ezért nem kivehető az egész bélyeg.

Méret: 36 x 41 x 3,8 cm

Leltári szám: nincs

LE[ - retrograd

Kat. 219. Bélyeges tégla töredéke, imbrex.

Bélyeg: LE[ - retrográd.

Méret: v. $2,1 \mathrm{~cm}$

Leltári szám: II-2918

Kat. 220. Bélyeges tégla töredéke, tegula.

Bélyeg: LE[ - retrográd. Az E betű csak részlegesen őrzödött meg.

Méret: v. $3,2 \mathrm{~cm}$

Leltári szám: nincs

Kat. 221. Bélyeges tégla töredéke, tegula.

Bélyeg: LE[

Méret: v. 3,2 cm

Leltári szám: II-2944

Kat. 222. Bélyeges tégla töredéke, tegula.

Előre mélyített mezőben fent három oldalt három, lent két háromszög $(0,3-0,4 \mathrm{~cm}$ szélességủek és magasságúak). Bélyeg: LE? - retrográd. A felszín több helyen sérült, ezért a bélyeg nehezen kivehető.

Méret: 36 x 19 x 3,8 cm

Leltári szám: nincs

Több bélyeg egy téglán:

Kat. 223. Bélyeges tégla töredéke, imbrex.

Dupla bélyeg ami részlegesen elfedik egymást. Az elsőből csak mintha egy tabula ansata keretelés, míg a másikon egy D betű vehető ki.

Méret: v. $2 \mathrm{~cm}$

Leltári szám: II-2880

Kat. 224. Bélyeges tégla töredéke, tegula.

Két bélyeg töredéke található. Feltételezhetően elhelyezkedésük alapján keresztezhették egymást. Az egyikből csak egy L, míg a másikból egy részleges I? Betű ismerhető fel.

Méret: v. 3,2-3,4 cm

Leltári szám: II-2199? Nagyon halvány 
Kat. 225. Bélyeges tégla töredéke, imbrex.

A tégla felszínén két bélyeg található (mindkét bélyeg a LEG I AD - tabula ansata keretben. Mindkét esetben a bélyeg alsó része hiányzik, így a betűk is csak részlegesen őrződtek meg. 1. bélyeg: LEG I AD, 2. bélyeg: LEG] I AD.

Méret: 30 x 20,5 x 2-2,4 cm

Leltári szám: nincs

Kat. 226. Bélyeges tégla töredéke, later.

A téglán két bélyeg nyomai ismerhetők fel. Mivel a felszín nagyon rossz megőrzödésű, repedezett az első bélyegből egy A, míg a másikból csak a keretelés egy része ismerhető fel.

Méret: 26,8 x 17,3 x 5-6 cm

Leltári szám: nincs

\section{Bélyeg nélküli illetve olvashatatlan bélye- gú leletek:}

Kat. 227. Bélyeges tégla töredéke, tegula?

Bélyeg: olvashatatlan, egyértelműen csak a $t a-$ bula ansata keretelés ismerhető fel. Felszín nagyon rossz állapotú, potyog szét.

Méret: v. 2,5-2,6 cm

Leltári szám: II-2168

Kat. 228. Bélyeges tégla töredéke, tegula.

Bélyeg: olvashatatlan, a felszín sérülése miatt.

Méret: v. $3 \mathrm{~cm}$

Leltári szám: nincs

Kat. 229. Bélyeges tégla töredéke, tegula.

Bélyeg: csak egy $C$ betű vehető ki illetve szemben vele mintha egy fordított $C$ körvonala volna.

Méret: v. 2,3 cm

Leltári szám: nincs

Kat. 230. Bélyeges tégla töredéke, imbrex.

Bélyeg: szinte olvashatatlan, talán LEG I AD? Retrográd bélyege?

Méret: v. 2,2 cm

Leltári szám: nincs

Kat. 231. Bélyeges tégla töredéke, tegula.

A felszínét meszes habarcsos anyag borítja, ezért a bélyeg megmaradt része olvashatatlan.

Méret: v. $3,5 \mathrm{~cm}$

Leltári szám: nincs
Kat. 232. Bélyeges tégla töredéke, tegula.

A felszín nagyon kopott. Pár betű nagyon halvány sziluetje ismerhető fel.

Méret: 29 x 29,5 x 2,3-2,6 cm

Leltári szám: nincs

Kat. 233. Bélyeges tégla töredéke, later.

A felszín egy részét habarcs borítja. A bélyeg nagyon kopott, részlegesen egy A betü sziluetje ismerhető fel középtájt.

Méret: 26,8 x 27 x 4,5-5,4 cm

Leltári szám: nincs

Kat. 234. Bélyeges tégla töredéke, tegula.

A bélyeg töredékes, felszíne nagyon kopott. Talán egy $\mathrm{F}$ betủ és talán tabula ansata keretelés töredéke ismerhető fel.

Méret: 55 x 28,5 x 3-3,8 cm

Leltári szám: nincs

Kat. 235. Bélyeges tégla töredéke, tegula.

A felszín nagyon kopott. részlegesen felismerhetö a keretelés.

Méret: 62,5 x 23,8 x 3,2-4,2 cm

Leltári szám: nincs

Kat. 236. Bélyeges tégla töredéke, tegula.

Csak a bélyeg kerete őrzödött meg.

Méret: 21 × 5,2 × 2,2 cm

Leltári szám: nincs

Kat. 237. Bélyeges tégla töredéke, tegula.

Csak a bélyeg kerete őrzödött meg.

Méret: 31,8 x 29,3 x 2,5-3 cm

Leltári szám: nincs

Kat. 238. Bélyeges tégla töredéke, tegula.

Csak a bélyeg eleje, talán tabula ansata kereteléssel? ismerhető fel.

Méret: v. 4-4,5 cm

Leltári szám: nincs

\section{Vésett felirat:}

Kat. 239. Feliratos tégla töredéke, tegula.

Vésett felirat: NO betűk felismerhetőek egy harmadik betű részlegesen kivehető a törésnél talán egy $\mathrm{P}$ ?

Méret: v. $2 \mathrm{~cm}$

Leltári szám: II-3034? - nagyon halvány 


\section{Irodalom}

AlAPI, Gy. 1915: A Komáromi Múzeum római régiségei. Archaeologiai Értesítő 35, 336-341.

Bakos, M. - LÁNyi, V. - ToRbÁgyi, M. 1994: Römische Münzen in der Museumssammlung. Komárno.

FeHÉrvÁryovÁ, M. 1986: Pôsobenie Múzea v rámci spolkovej činnosti (1886-1945). In: Sto rokov Múzea v Komárne 1886-1986. Komárno, 11-46.

FÉnYes, E. 1984: Magyarország geographiai szótára I. Szeged.

FÉNYes, E. 1994: Komárom vármegye leírása (1848). Pozsony.

GASPÁR, D. - RATIMORSKÁ, P. 1983: Kovania debničiek, zámky, držadlá, klúče, klince a fragmenty panciera. Komárno.

GyulaI, R. 1888a: Adalékok megyénk római hódoltsága korához. A Komárom-vármegyei és Komárom városi Történeti és Régészeti Egylet 1887. évi jelentése, 1-10.

GyulaI, R. 1888b: Az egylet gyüjteménye. A Komárom-vármegyei és Komárom városi Történeti és Régészeti Egylet 1887. évi jelentése, 42-48.

GyulaI, R. 1889a: Az egylet gyüjteménye. A Komárom-vármegyei és Komárom városi Történeti és Régészeti Egylet 1888. évi jelentése, 7-15.

GyulaI, R. 1889b: Kalauz a Komárommegyei és Városi Történet-Régészeti-egylet Muzeumában. Komárom.

HARL, O. - Lőrincz, B. 2002: Római kôtár VI. bástya, Komárom. Komárno - Wien.

HrNČIARIK, E. 2012: Rímske kostené výrobky v zbierke Podunajského múzea v Komárne. Komárno.

Kuzmová, K. 1992: Terra Sigillata v zbierkach múzea. Komárno.

MÁczA, M. 2011: Prehlad dejín múzea (1886-2011). In: 125 rokov Múzea v Komárne 1886-2011. Komárno, 10-23.

MıLCH, Á. 1903: A monostori ásatások. A Komáromvármegyei és Városi Muzeum-egyesület 1901/2. évi értesitóje, 39-44.

RATIMORSKÁ, P. 1984: Rímske kamenné pamiatky v zbierkach Múzea. Komárno.

RATimoRskÁ, P. - ViRÁGH, J. 1986: Výstavy Múzea (1886-1984). In: Sto rokov Múzea v Komárne 18861986. Komárno, 164-177.

SzILÁGyi, J. 1933: A Pannoniai bélyeges téglák. Budapest.

Tóth Kurucz, J. 1907 : Leányvár. A Komáromvármegyei és Városi Muzeum-egyesület 1906. évi értesítője, $40-68$.

Tóтн KuRUCz, J. 1908: A leányvári ásatások folytatása 1907-ben. A Komáromvármegyei és Városi Muzeum-egyesület 1907. évi értesitője, 42-56.

Tótн Kurucz, J. 1909: A leányvári ásatások folytatása 1908-ban. A Komáromvármegyei és Városi Muzeum-egyesület 1908. évi értesitóje, 46-55.

Tótн Kurucz, J. 1910: A leányvári ásatások folytatása 1909-ben. A Komáromvármegyei és Városi Muzeum-egyesület 1909. évi értesítóje, 90-94.

Weszelovszky, J. 1903a: A Múzeum 1901 és 1902. évi gyarapodása. A Komáromvármegyei és Városi Muzeum-egyesület 1901/2. évi értesitóje, 9-14. 
Weszelovszky, J. 1903b: Ásatások. A Komáromvármegyei és Városi Muzeum-egyesület 1901/2. évi értesítője, 14-15.

Weszelovszky, J. 1904: Ásatások. A Komáromvármegyei és Városi Muzeum-egyesület 1903. évi értesitője, $10-11$.

ŽundÁLEK, I. - ŽundÁLEKovÁ, B. 2012: Rímske lampy a svietniky v zbierke Podunajského múzea v Komárne. Komárno. 


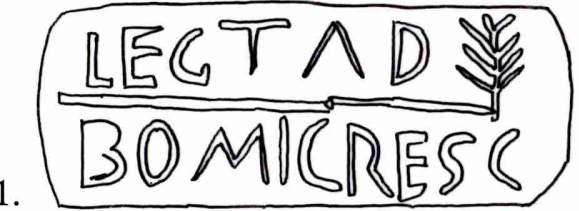 \\ 3. $5 \mathrm{~S}, \mathrm{~N} C 5 \sqrt{5} \sqrt{5}$}

2.

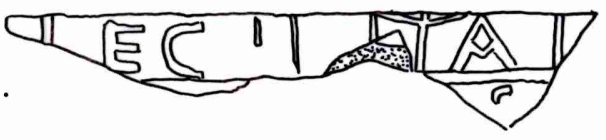

4.

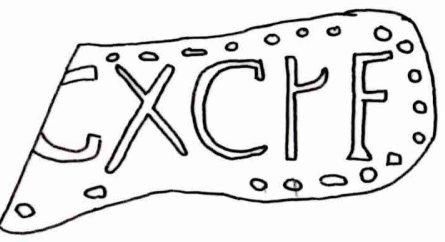

5. शㄱ제제

7.

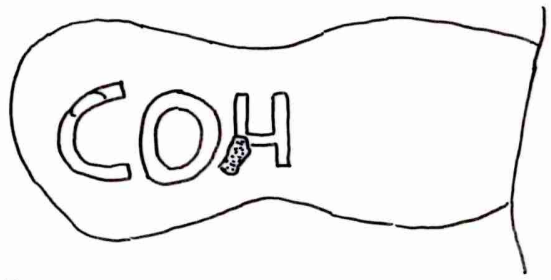

$5 \mathrm{~cm}$

6.

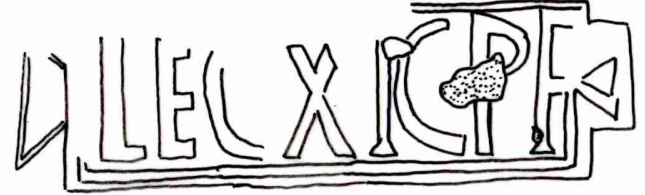

Fig. 1. 
9.

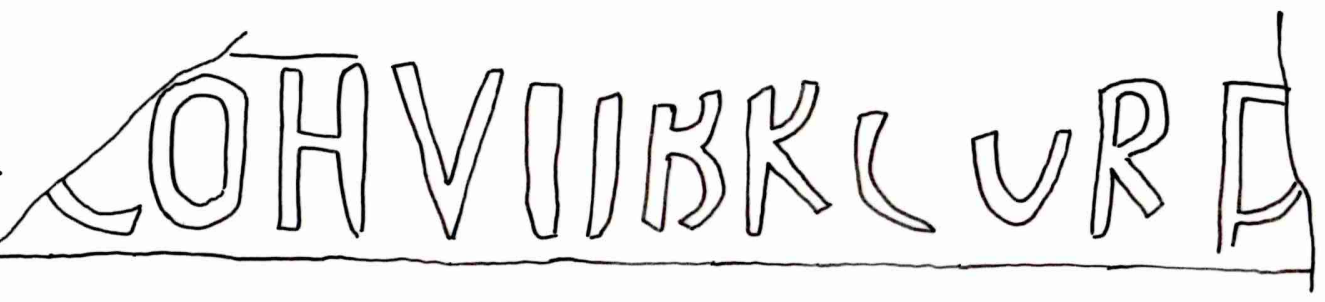

10.
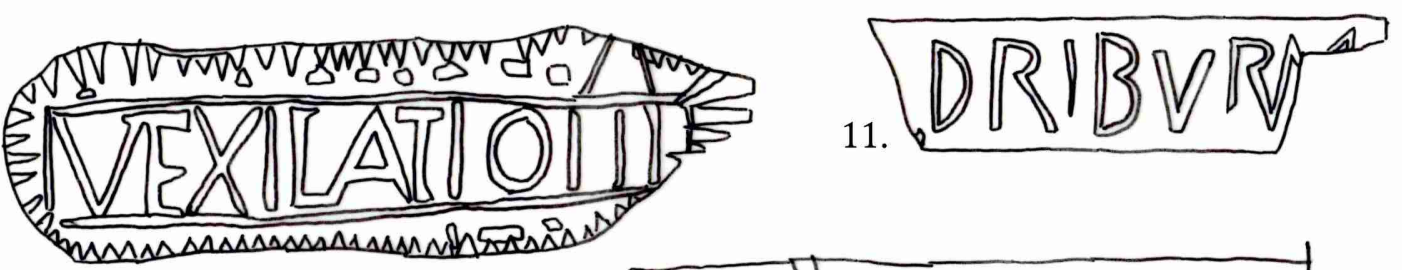

12.

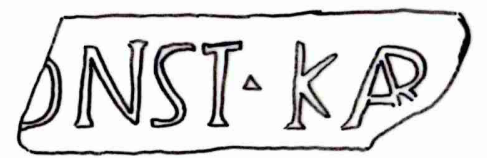

13.

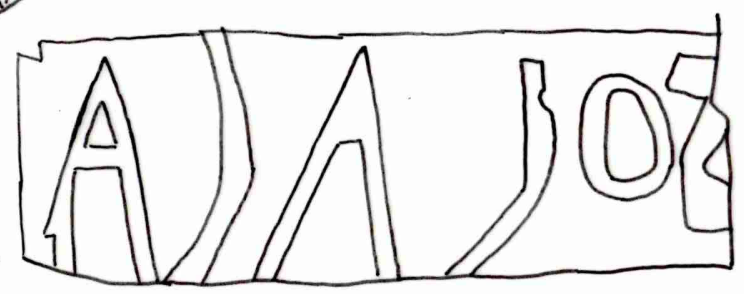

14.

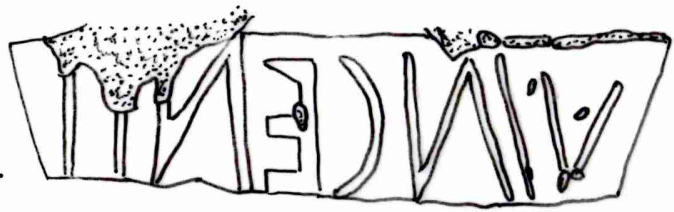

$5 \mathrm{~cm}$

Fig. 2.
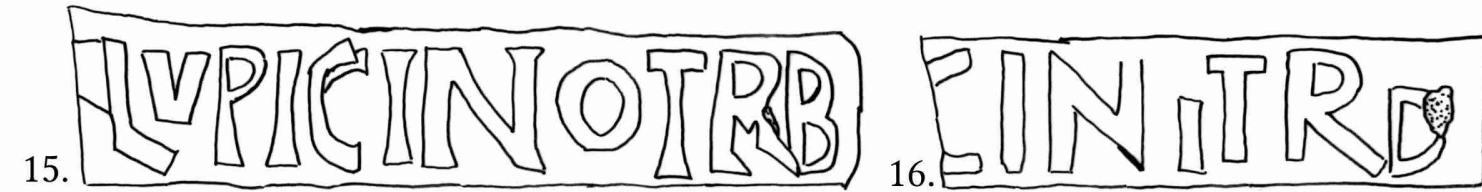

$$
\text { 17. }
$$

19.
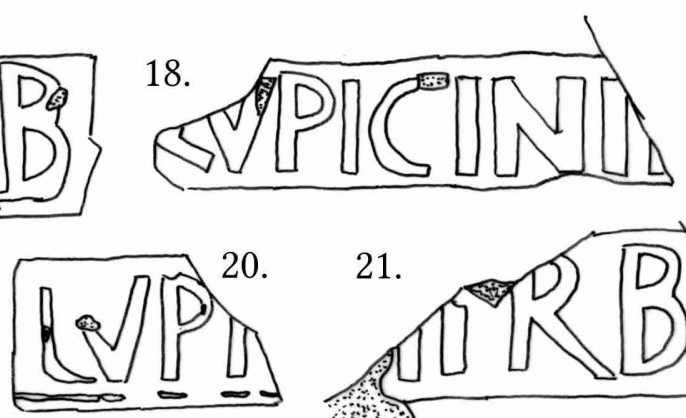

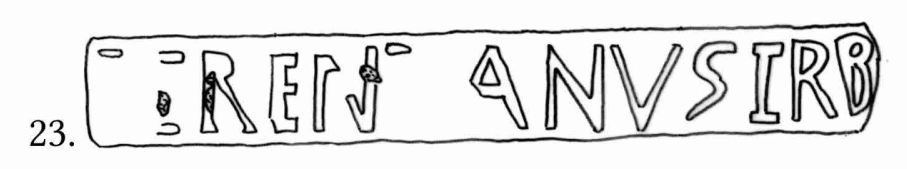

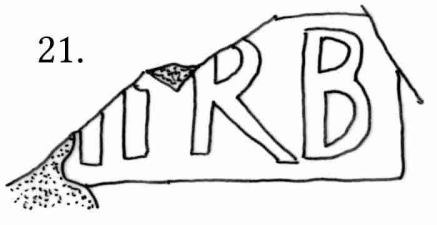

Fig. 3. 
42.

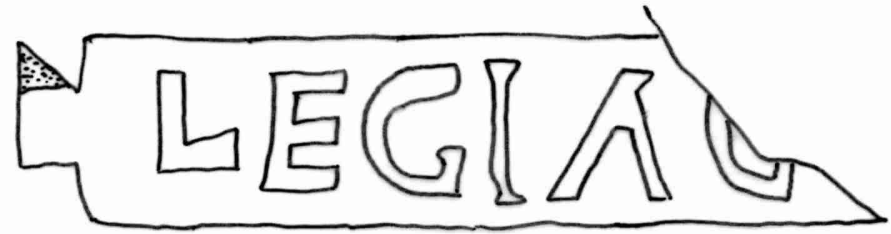

50.

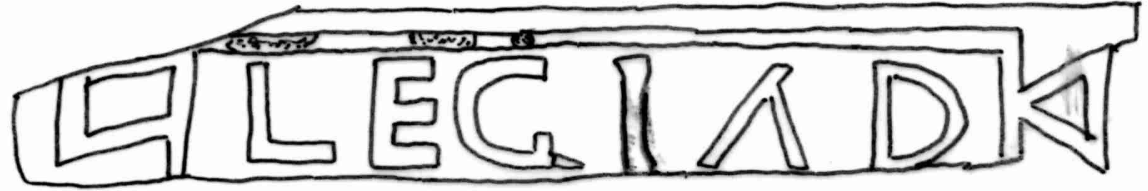

${ }_{60}$ AESIRD包

64. पLGIAD

62.

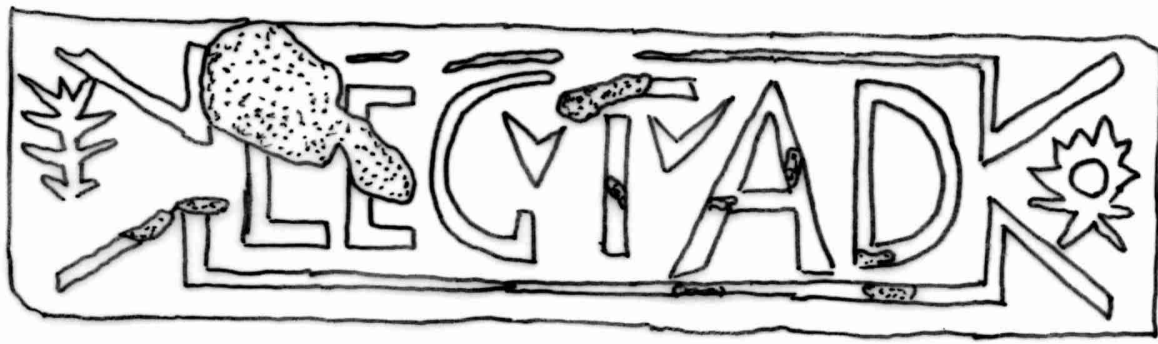

71.

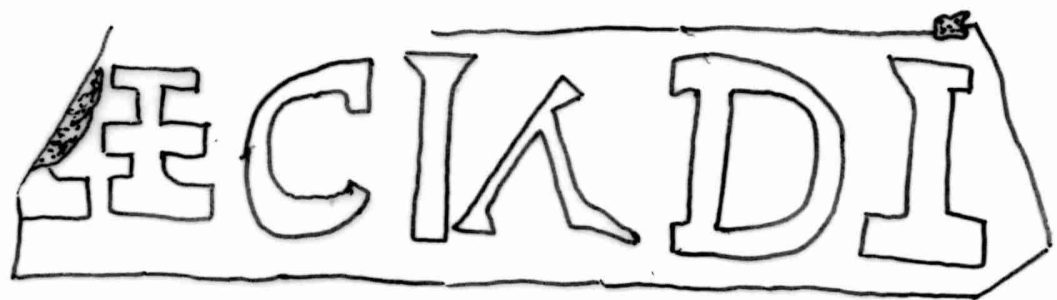

72.

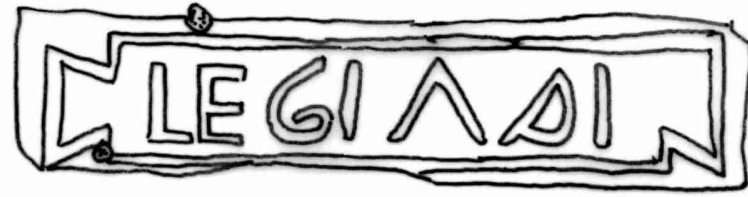

$5 \mathrm{~cm}$

103.

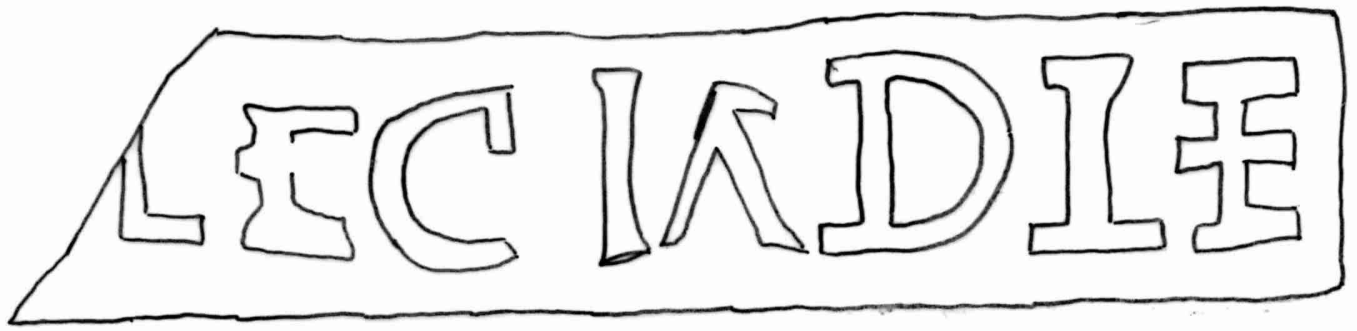

Fig. 4. 


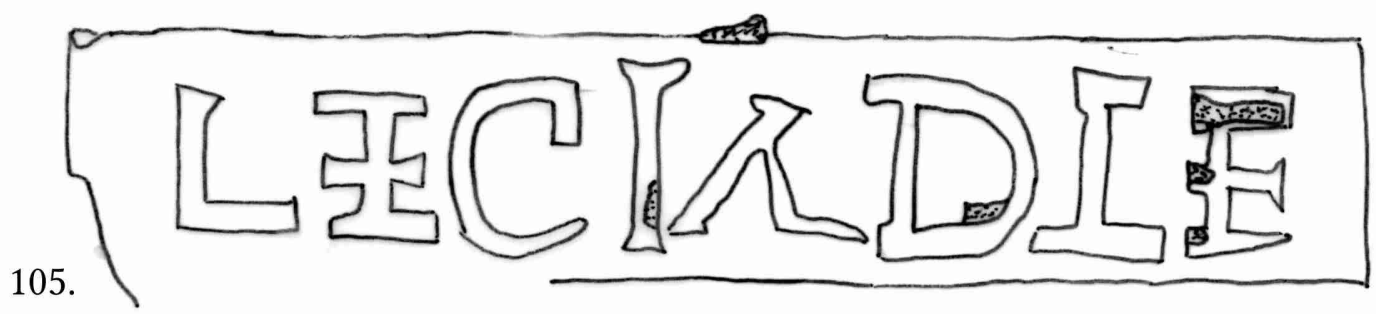

107.

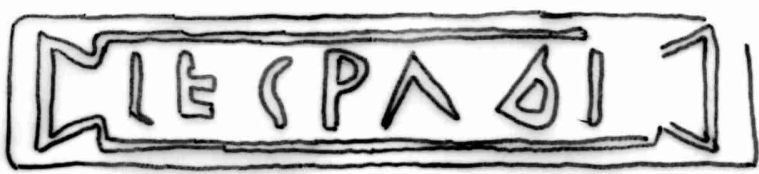

110.

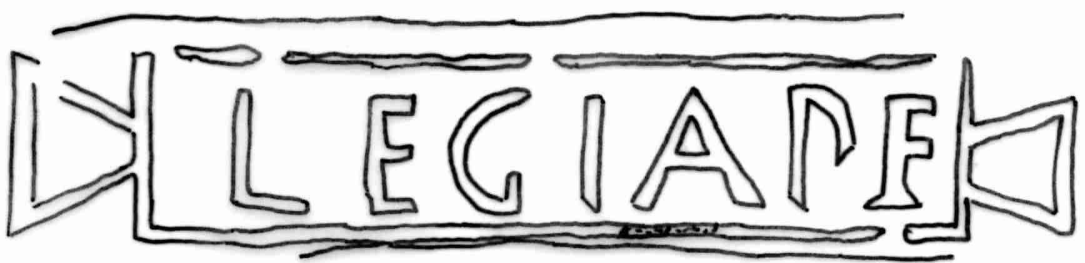

112.

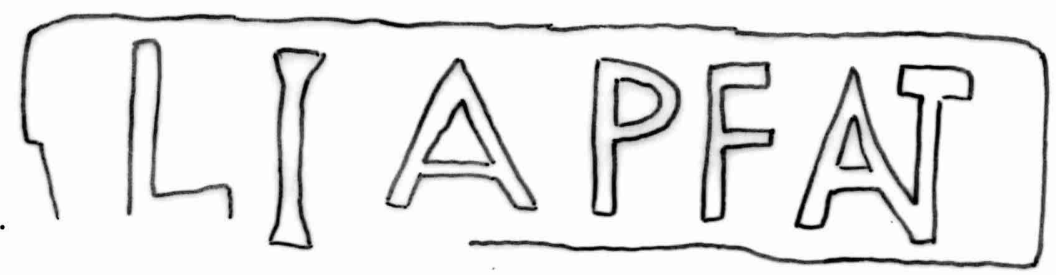

121.

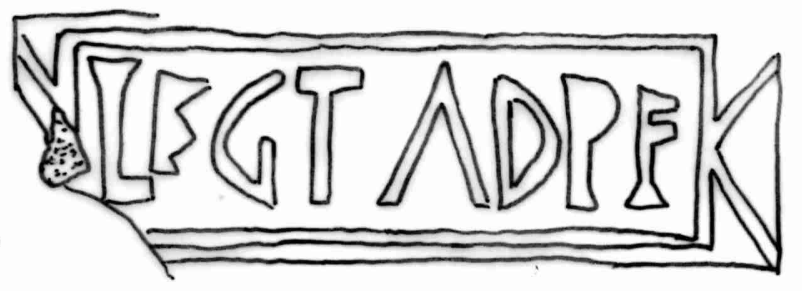

129.

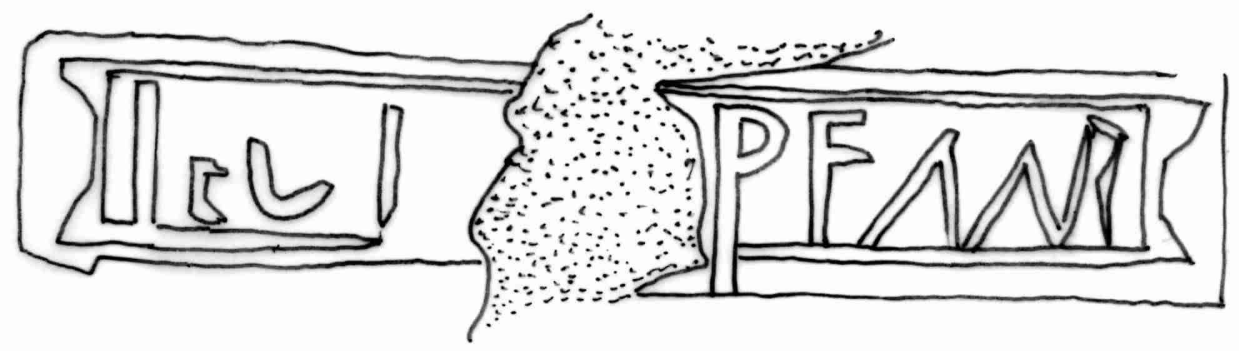

130.

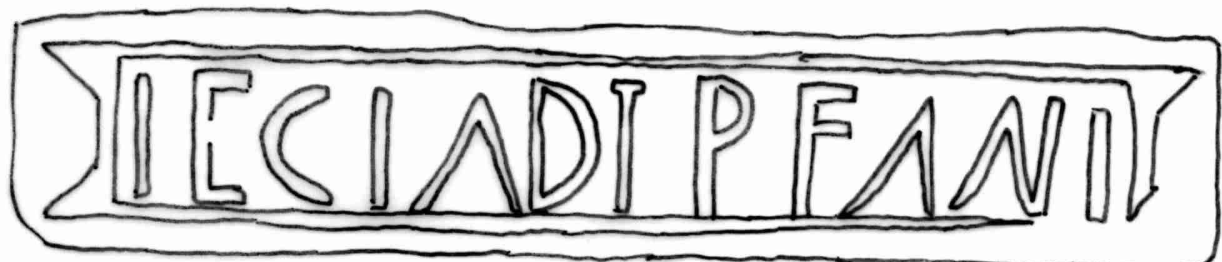

$5 \mathrm{~cm}$

Fig. 5. 
139.

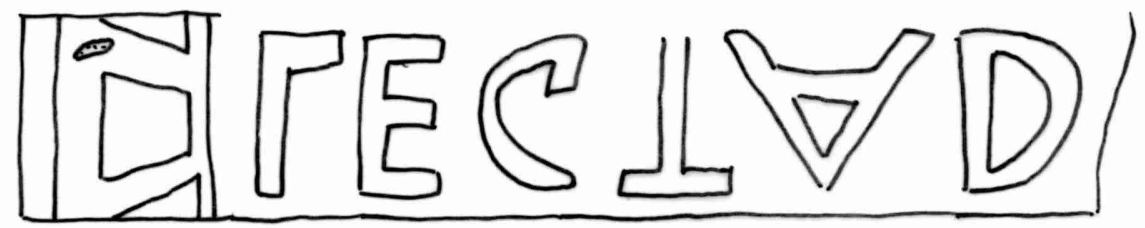

157.
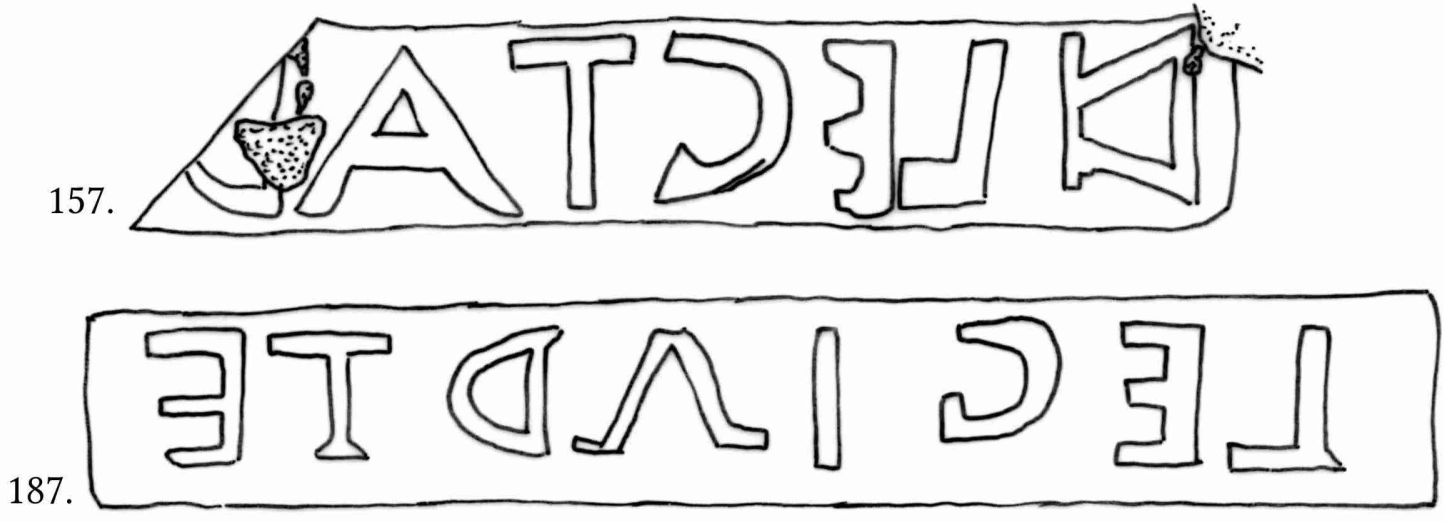

198.

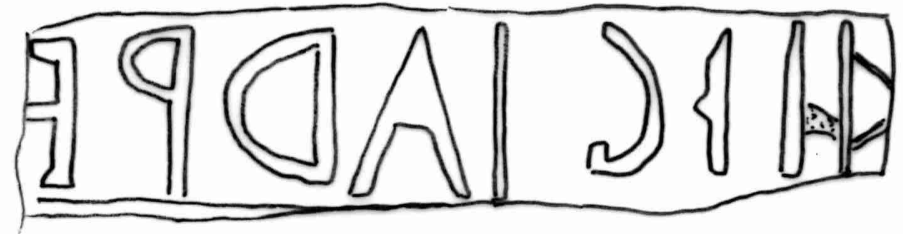

200.

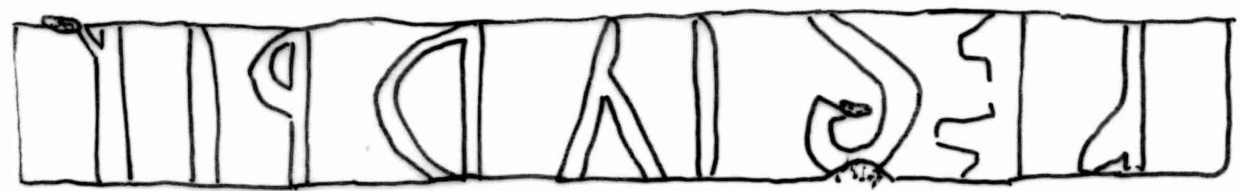

$5 \mathrm{~cm}$

Fig. 6. 